\title{
Article
}

\section{Design, Synthesis and Anticancer Profile of New 4-(1H-benzo[d]imidazol-1-yl)pyrimidin-2-amine-Linked Sulfonamide Derivatives with V600EBRAF Inhibitory Effect}

\author{
Mohammed S. Abdel-Maksoud ${ }^{1, *},+$, Ahmed A. B. Mohamed ${ }^{2,+}$, Rasha M. Hassan ${ }^{1}$, Mohamed A. Abdelgawad ${ }^{3}{ }^{1}$, \\ Garri Chilingaryan ${ }^{4}\left(\mathbb{D}\right.$, Samy Selim ${ }^{5}{ }^{(D}$, Mohamed S. Abdel-Bakky ${ }^{6}$ and Mohammad M. Al-Sanea ${ }^{3, *(\mathbb{D}}$ \\ 1 Pharmaceutical and Drug Industries Research Division, Medicinal \& Pharmaceutical Chemistry Department, \\ National Research Centre (ID: 60014618), Dokki, Giza 12622, Egypt; rashahassan_pharma@yahoo.ca \\ 2 Department of Medicinal Chemistry, Faculty of Pharmacy, Mansoura University, Mansoura 35516, Egypt; \\ ahmed_smt@yahoo.com \\ 3 Department of Pharmaceutical Chemistry, College of Pharmacy, Jouf University, Sakaka 72341, Saudi Arabia; \\ mhmdgwd@ju.edu.sa \\ 4 Institute of Molecular Biology of NAS, Yerevan 0014, Armenia; g_chilingaryan@mb.sci.am \\ 5 Department of Clinical Laboratory Sciences, College of Applied Medical Sciences, Jouf University, \\ Sakaka 72341, Saudi Arabia; sabdulsalam@ju.edu.sa \\ check for \\ Citation: Abdel-Maksoud, M.S.; \\ Mohamed, A.A.B.; Hassan, R.M.; \\ Abdelgawad, M.A.; Chilingaryan, G.; \\ 6 Department of Pharmacology and Toxicology, College of Pharmacy, Qassim University, \\ Buraydah 51452, Saudi Arabia; m.abdelbakky@qu.edu.sa \\ * Correspondence: ms.abdel-maksoud@nrc.sci.eg (M.S.A.-M.); mmalsanea@ju.edu.sa (M.M.A.-S.) \\ + These authors are equally contributed to this work.
} Selim, S.; Abdel-Bakky, M.S.; Al-Sanea, M.M. Design, Synthesis and Anticancer Profile of New 4-(1H-benzo[ $d$ ]imidazol-1yl)pyrimidin-2-amine-Linked Sulfonamide Derivatives with V600EBRAF Inhibitory Effect. Int. J Mol. Sci. 2021, 22, 10491. https:// doi.org/10.3390/ijms221910491

Academic Editors: Alessio Nocentini, Wagdy M. Eldehna and

Stanislav Kalinin

Received: 24 August 2021

Accepted: 22 September 2021

Published: 28 September 2021

Publisher's Note: MDPI stays neutral with regard to jurisdictional claims in published maps and institutional affiliations.

Copyright: (c) 2021 by the authors. Licensee MDPI, Basel, Switzerland. This article is an open access article distributed under the terms and conditions of the Creative Commons Attribution (CC BY) license (https:/ / creativecommons.org/licenses/by/ $4.0 /)$.
Abstract: A new series of 4-(1H-benzo[d]imidazol-1-yl)pyrimidin-2-amine linked sulfonamide derivatives 12a-n was designed and synthesized according to the structure of well-established V600EBRAF inhibitors. The terminal sulfonamide moiety was linked to the pyrimidine ring via either ethylamine or propylamine bridge. The designed series was tested at fixed concentration $(1 \mu \mathrm{M})$ against V600EBRAF, finding that $\mathbf{1 2 e}, \mathbf{1 2} \mathbf{i}$ and $\mathbf{1 2 l}$ exhibited the strongest inhibitory activity among all target compounds and $\mathbf{1 2 l}$ had the lowest $\mathrm{IC}_{50}$ of $0.49 \mu \mathrm{M}$. They were further screened on NCI 60 cancer cell lines to reveal that 12e showed the most significant growth inhibition against multiple cancer cell lines. Therefore, cell cycle analysis of 12e was conducted to investigate the effect on cell cycle progression. Finally, virtual docking studies was performed to gain insights for the plausible binding modes of vemurafenib, $\mathbf{1 2 i}, \mathbf{1 2}$ e and $\mathbf{1 2 1}$.

Keywords: anticancer; BRAF inhibitors; synthesis; benzimidazole; sulfonamide; cell cycle; virtual docking

\section{Introduction}

Cancer refers to a number of diseases characterized by the development of uncontrollable cells that can infiltrate and destroy normal body tissue. It is considered the second major cause of death after cardiovascular diseases [1,2]. In terms of 2020 statistics, it is the main cause of death in 112 out of 183 countries [3]. Traditional chemotherapeutics have severe and lethal side effects and have diminished efficacy owing to drug resistance [4,5]. Therefore, there is urgent need to explore new potent drugs with fewer side effects and higher efficacy.

The MAPK cascade, which includes RAS (Rat sarcoma virus kinase), RAF(Rapidly Accelerated Fibrosarcoma kinase), ERK (Extracellular signal-regulated kinase), and MEK (mitogen-activated protein kinase kinase) kinases, is considered one of the vital signaling pathways that controls cell function and proliferation [6-9]. BRAF (a serine/threonine kinase) is the key activator promoter of MAPK signaling pathway. The hyperactivation of MAPK pathway due to oncogenic mutation of BRAF (Rapidly Accelerated Fibrosarcoma 
kinase isoform B) occurs in 70\% of melanoma cases [10,11], 10\% of colorectal cases [12], and $70 \%$ of thyroid cancer cases [13-15]. The main oncogenic mutation of BRAF occurs when the valine amino acid in position 600 is replaced by glutamic acid to produce V600EBRAF, which is the major mutation in melanomas [16-20] and papillary thyroid carcinomas [10], accounting for up to $63 \%$ in melanoma and $50 \%$ in papillary thyroid carcinomas. This, in turn, has drawn attention to the possibility of targeting V600EBRAF as a treatment for melanoma with hyperactive MAPK pathways [21-23].

Sorafenib (Nexavar ${ }^{\circledR}$, BAY- 43-9006) was the first multikinase inhibitor to have a dual inhibitory activity against BRAF and CRAF (Rapidly Accelerated Fibrosarcoma kinase isoform C) $[24,25]$. Vemurafenib was the first selective V600EBRAF inhibitor with sulfonamide moiety to be approved for the treatment of melanoma [26]. In addition, PLX 4720, encorafenib, and dabrafenib showed selective V600EBRAF inhibitory activity for the treatment of late-stage melanoma via induction of programmed cell death (Figure 1) [27,28]. It is worth noting that melanoma without mutated BRAF was not treated by either vemurafenib or dabrafenib $[25,29,30]$.

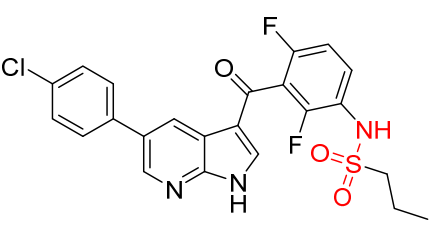

Vemurafenib<smiles>CCCS(=O)(=O)Nc1ccc(F)c(C(=O)c2c[nH]c3ncc(Cl)cc23)c1F</smiles>

PLX-4720<smiles>COC(=O)NC(C)CNc1cc(-c2cn(C(C)C)nc2-c2cc(Cl)cc(NS(C)(=O)=O)c2F)ccn1</smiles>

Encorafenib (LGX818)<smiles>CC(C)(C)c1nc(-c2cccc(NS(=O)(=O)c3c(F)cccc3F)c2F)c(-c2ccnc(N)n2)s1</smiles>

Dabrafenib

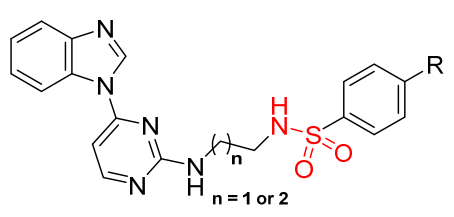

Target compounds

Figure 1. Structures of known sulfonamide-based V600EBRAF inhibitors and the new target compounds (sulfonamide moiety in red colour).

Benzimidazole is a heterocyclic compound composed of two fused rings of benzene and imidazole. It is a constitutional isomer for azaindole ring that is present in the vemurafenib family. It shows a vast range of therapeutic activities including anticancer [31-34], antiviral [35-37], antifungal [38,39], and anthelmintic effects [40-42].

In our previous work, different series of compounds containing sulfonamide moiety showed high inhibitory activity towards V600EBRAF, wild-type BRAF, and CRAF. Different backbone scaffolds were evaluated such as pyrazole, imidazole, imidazothiazole, imidazoxazole, and azaindole [43-49]. In the present work, pyrimidinylbenzimidazole scaffold was used as a main backbone for the new sulfonamide derivatives. The linker between sulfonamide moiety and pyrimidine is either ethylamino or propylamino bridge. The target compounds were screened for their inhibitory effect over V600EBRAF at fixed concentration. To check both potency and selectivity, we determined the $\mathrm{IC}_{50}$ of the target compounds over V600EBRAF, wild-type BRAF, and CRAF. The final compounds were subsequently submitted to $\mathrm{NCI}$ (National Cancer institution) to investigate their effect on different cancer cell lines. Moreover, cell cycle analysis for the most promising compound was performed. 


\section{Results and Discussion}

\subsection{Chemistry}

Final compounds 12a-n were prepared via three distinct steps. The first step includes the synthesis of main intermediate 1-(2-(methylsulfonyl) pyrimidin-4-yl)-1H-benzo[d]imida zole (4) starting from o-phenylenediamine (1) (Scheme 1). The second step involves the synthesis of terminal side chain 11a-n starting from ethanolamine (5a) and propanolamine $(\mathbf{5 b})$ (Scheme 2). Finally, coupling of $\mathbf{4}$ and 11a-n led to the formation of the target compounds 12a-n.

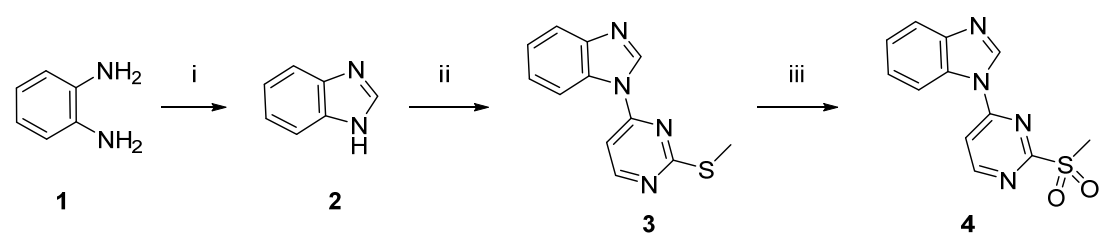

Scheme 1. Synthetic pathway for the key intermediate 4. Reagents and conditions: (i) formic acid, $\mathrm{NaOH}$; (ii) 4-chloro-2-(methylthio)pyrimidine, $\mathrm{NaH}, \mathrm{DMF}$, rt; (iii) Oxone, $\mathrm{MeOH} / \mathrm{H}_{2} \mathrm{O}$, rt.

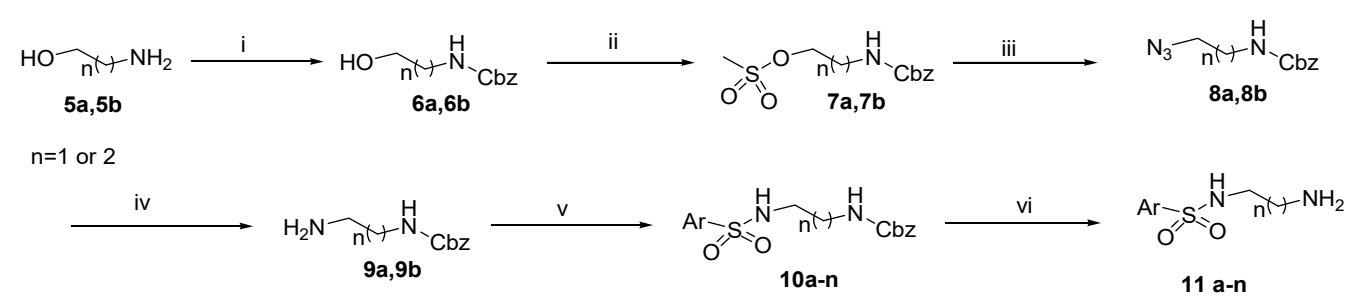

Scheme 2. Synthetic pathway of the terminal side chains 11a-n. Reagents and conditions: (i) TEA, benzyl chlorocarbonate, DCM, $0{ }^{\circ} \mathrm{C}, 12 \mathrm{~h}$; (ii) TEA, methane sulfonyl chloride, DCM, $0{ }^{\circ} \mathrm{C}, 4 \mathrm{~h}$; (iii) $\mathrm{NaN}_{3}$, DMSO, $70{ }^{\circ} \mathrm{C}, 2 \mathrm{~h}$; (iv) $\mathrm{Ph}_{3} \mathrm{P}, \mathrm{MeOH}$, reflux, $2 \mathrm{~h}$; (v) trimethyl amine, suitable benzenesufonyl chloride, $\mathrm{DCM}, 0{ }^{\circ} \mathrm{C}$; (vi) $\mathrm{Pd} / \mathrm{C}, \mathrm{H}_{2}, \mathrm{MeOH}, \mathrm{rt}, 2 \mathrm{~h}$.

As illustrated in Scheme 1, heating a mixture of o-phenylenediamine (1) and 90\% formic acid at $100{ }^{\circ} \mathrm{C}$ for $2 \mathrm{~h}$ and then cooling the mixture followed by slow addition of $10 \%$ $\mathrm{NaOH}$ led to the precipitation of $1 \mathrm{H}$-benzo[d]imidazole (2). Arylation of 2 with 4-chloro-2(methylthio) pyrimidine applying $\mathrm{NaH}$ as a base in DMF afforded 1-(2-(methylthio)pyrimidin4-yl)-1H-benzo[d]imidazole (3), which upon oxidation by oxone in a mixture of $\mathrm{MeOH}$ and $\mathrm{H}_{2} \mathrm{O}$ led to the formation of the key intermediate 1-(2-(methylsulfonyl)pyrimidin-4-yl)- $1 \mathrm{H}-$ benzo[d]imidazole (4).

Next, we turned our attention to the synthesis of the terminal side chains 11a-n, as shown in Scheme 2. It involves the reaction of ethanolamine $(5 \mathbf{a})$ or propanolamine $(\mathbf{5 b})$ with benzyl chloroformate using triethyl amine as a base in DCM to give N-protected ethanolamine (6a) or propanolamine (6b). Reaction of $\mathbf{6}$ with methane sulfonyl chloride using trimethylamine as a base in DCM afforded 2-(((benzyloxy) carbonyl) amino) ethyl methane sulfonate (7a) or 2-(((benzyloxy) carbonyl) amino) propyl methane sulfonate (7b). Replacement of the mesylate group by azide via heating 7 with sodium azide in DMSO gave benzyl(2-azidoethyl)carbamate (8a) or benzyl(2-azidopropyl)carbamate (8b). Reduction of 8 by applying Staudinger reduction using triphenylphosphine and heating in $\mathrm{MeOH}$ led to the formation of benzyl(2-aminoethyl)carbamate (9a) or benzyl(2-aminopropyl)carbamate (9b). Reaction of 9 with arylsulfonyl chloride in DCM and trimethyl amine afforded 10a-n. Deprotection of $\mathbf{1 0}$ using $\mathrm{Pd} / \mathrm{C}$ under $\mathrm{H}_{2}$ atmosphere in $\mathrm{MeOH}$ led to the formation of the terminal side chains 11a-n.

Finally, reaction of 4 with 11a-n in DMSO in presence of diisopropyl ethyl amine afforded the target compounds 12a-n in 52-81\% isolated yield (Scheme 3, Table 1). 


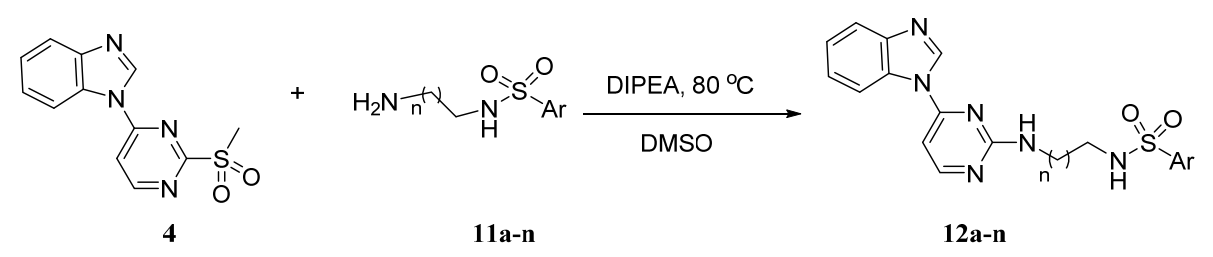

Scheme 3. Synthesis of the final compounds $\mathbf{1 2 a} \mathbf{a}-\mathbf{n}$.

Table 1. General structure and yields of the final compounds 12a-n.

\begin{tabular}{|c|c|c|c|c|c|c|c|}
\hline Comp. & $\mathbf{n}$ & $\mathbf{R}$ & Yield $^{1}$ & Comp. & $\mathbf{n}$ & $\mathbf{R}$ & Yield $^{1}$ \\
\hline $12 a$ & 1 & $\mathrm{H}$ & $71 \%$ & $12 \mathrm{~h}$ & 2 & $\mathrm{H}$ & $64 \%$ \\
\hline $12 b$ & 1 & $4-F$ & $74 \%$ & $12 \mathrm{i}$ & 2 & $4-F$ & $59 \%$ \\
\hline $12 \mathrm{c}$ & 1 & $4-\mathrm{Cl}$ & $77 \%$ & $12 j$ & 2 & $4-\mathrm{Cl}$ & $59 \%$ \\
\hline $12 d$ & 1 & $4-\mathrm{Br}$ & $70 \%$ & $12 \mathrm{k}$ & 2 & $4-\mathrm{Br}$ & $64 \%$ \\
\hline $12 e$ & 1 & $4-\mathrm{CF}_{3}$ & $62 \%$ & 121 & 2 & $4-\mathrm{CF}_{3}$ & $69 \%$ \\
\hline $12 f$ & 1 & $4-\mathrm{OCH}_{3}$ & $81 \%$ & $12 \mathrm{~m}$ & 2 & $4-\mathrm{OCH}_{3}$ & $70 \%$ \\
\hline $12 \mathrm{~g}$ & 1 & $4-\mathrm{CH}_{3}$ & $52 \%$ & $12 n$ & 2 & $\begin{array}{c}\text { Fused } \\
\text { benzene }\end{array}$ & $72 \%$ \\
\hline
\end{tabular}

${ }^{1}$ Isolated yield after silica gel column chromatography.

\subsection{Biology}

\subsubsection{Enzyme Assay}

The target compounds 12a-n were designed to be V600EBRAF inhibitors, and therefore the first screening stage was to detect their ability to inhibit V600EBRAF at a fixed concentration of $1 \mu \mathrm{M}$. All target compounds showed certain inhibitory effect on V600EBRAF (Table 2). Generally, 12h-n (with propylamine linker between pyrimidine ring and sulfonamide terminal) showed higher percent inhibition compared to 12a-g (with ethylamine linker between pyrimidine ring and sulfonamide terminal). However, it was found that $12 \mathrm{~m}$ ( $p$-OMe substituted benzene sulfonamide terminal) has lower percent inhibition compared to its ethylamine analogue $\mathbf{1 2 f}$.

Table 2. Percent inhibition of compound 12a-n over V600EBRAF at single dose $(1 \mu \mathrm{M})$.

\begin{tabular}{cccc}
\hline Comp. & \% Inhibition at $\mathbf{1} \boldsymbol{\mu \mathbf { M } ^ { \mathbf { 1 } }}$ & Comp. & \% Inhibition at $\mathbf{1} \boldsymbol{\mu} \mathbf{M}^{\mathbf{1}}$ \\
\hline $\mathbf{1 2 a}$ & $30.35 \pm 0.41$ & $\mathbf{1 2 h}$ & $49.54 \pm 0.61$ \\
$\mathbf{1 2 b}$ & $75.17 \pm 0.27$ & $\mathbf{1 2 i}$ & $97.81 \pm 0.82$ \\
$\mathbf{1 2} \mathbf{c}$ & $70.55 \pm 0.71$ & $\mathbf{1 2 j}$ & $88.14 \pm 0.19$ \\
$\mathbf{1 2 d}$ & $69.28 \pm 0.51$ & $\mathbf{1 2 k}$ & $73.81 \pm 0.75$ \\
$\mathbf{1 2} \mathbf{e}$ & $98.24 \pm 0.44$ & $\mathbf{1 2 l}$ & $98.75 \pm 0.58$ \\
$\mathbf{1 2 f}$ & $55.21 \pm 0.52$ & $\mathbf{1 2 m}$ & $51.26 \pm 0.29$ \\
$\mathbf{1 2 g}$ & $82.11 \pm 0.32$ & $\mathbf{1 2 n}$ & $41.27 \pm 0.46$ \\
Sorafenib & $84.57 \pm 0.77$ & & \\
\hline
\end{tabular}

${ }^{1}$ Percent inhibition values presented as mean \pm S.D. of two experiments.

Regarding the ethylamine linker containing $\mathbf{1 2 a}-\mathbf{g}$, 12e with $p-\mathrm{CF}_{3}$ substituted benzene sulfonamide terminal had the highest percent inhibition with mean value of $98 \%$, followed by $12 \mathrm{~g}$ with $p-\mathrm{CH}_{3}$ substituted benzene sulfonamide terminal with mean percent inhibition of $82 \%$. Furthermore, $p$-halobenzene sulfonamide derivatives $\mathbf{1 2 b}$-d showed size-dependent activity; the compound with smaller size halide $\mathbf{1 2 b}(p-\mathrm{F})$ showed the highest percent inhibition with mean value of $75 \%$, followed by $12 \mathrm{c}(p-\mathrm{Cl})$ with mean 
percent inhibition $71 \%$ and finally 12d ( $p$-Br) with mean percent inhibition of $69 \%$. 12a (unsubstituted) and $\mathbf{1 2 f}$ ( $p$-OMe) showed the lowest activities with mean percent inhibitions of $30 \%$ and $55 \%$, respectively.

On the other hand, 12h-n showed higher percent inhibition compared to the ethylamine analogues 12a-g. 121 ( $p-\mathrm{CF}_{3}$ sulfonamide terminal) exhibited the highest percent inhibition with mean value of $99 \%$. Compounds with $p$-halobenzene sulfonamide terminal 12i-k showed relatively high size dependent activity. Compound $\mathbf{1 2} \mathbf{i}(p-\mathrm{F})$ showed the highest activity with mean percent inhibition of $98 \%$, followed by $\mathbf{1 2} \mathbf{j}(p-\mathrm{Cl})$ with mean percent inhibition of $88 \%$, and finally $12 \mathrm{k}(p-\mathrm{Br})$ with mean percent inhibition of $74 \%$. Compounds $12 \mathrm{~h}$ (unsubstituted) and $12 \mathrm{~m}$ ( $p$-OMe) had moderate activity with mean percent inhibitions of 50\% and 51\%, respectively. 11n (naphthyl) showed the lowest activity, with mean percent inhibition of $41 \%$.

Next, we focused on determination of the potency $\left(\mathrm{IC}_{50}\right)$ of each compound over V600EBRAF and finding the selectivity for V600EBRAF over wild-type BRAF and CRAF. Most compounds showed relatively high potency towards V600EBRAF with submicro molar $\mathrm{IC}_{50}$ values (Table 3).

Table 3. $\mathrm{IC}_{50}(\mu \mathrm{M}){ }^{1}$ of the target compounds 12a-n over BRAF (wild-type), V600EBRAF and CRAF.

\begin{tabular}{cccc}
\hline Comp. & BRAF (Wild Type) & V600EBRAF & CRAF \\
\hline $\mathbf{1 2 a}$ & $3.250 \pm 0.450$ & $1.910 \pm 0.140$ & $2.980 \pm 0.210$ \\
$\mathbf{1 2 b}$ & $1.510 \pm 0.220$ & $0.740 \pm 0.051$ & $1.340 \pm 0.190$ \\
$\mathbf{1 2 c}$ & $1.380 \pm 0.170$ & $0.820 \pm 0.024$ & $1.490 \pm 0.230$ \\
$\mathbf{1 2 d}$ & $1.790 \pm 0.150$ & $0.910 \pm 0.019$ & $2.10 \pm 0.180$ \\
$\mathbf{1 2} \mathbf{1}$ & $\mathbf{1 . 2 5 0} \pm \mathbf{0 . 0 9 5}$ & $\mathbf{0 . 6 2 0} \pm \mathbf{0 . 0 3 1}$ & $1.140 \pm 0.088$ \\
$\mathbf{1 2 f}$ & $1.980 \pm 0.120$ & $0.980 \pm 0.020$ & $1.670 \pm 0.210$ \\
$\mathbf{1 2 g}$ & $1.530 \pm 0.260$ & $0.790 \pm 0.042$ & $1.480 \pm 0.099$ \\
$\mathbf{1 2 h}$ & $2.320 \pm 0.110$ & $1.120 \pm 0.098$ & $2.140 \pm 0.078$ \\
$\mathbf{1 2} \mathbf{1 2}$ & $1.330 \pm 0.081$ & $\mathbf{0 . 5 3 0} \pm \mathbf{0 . 0 2 2}$ & $0.980 \pm 0.044$ \\
$\mathbf{1 2} \mathbf{1 2 k}$ & $1.130 \pm 0.099$ & $\mathbf{0 . 7 9 0} \pm \mathbf{0 . 0 5 1}$ & $1.020 \pm 0.077$ \\
$\mathbf{1 2 1}$ & $1.530 \pm 0.110$ & $0.810 \pm 0.056$ & $0.990 \pm 0.085$ \\
$\mathbf{1 2 m}$ & $0.940 \pm 0.065$ & $\mathbf{0 . 4 9 0} \pm \mathbf{0 . 0 6 1}$ & $0.840 \pm 0.076$ \\
$\mathbf{1 2 n}$ & $1.460 \pm 0.086$ & $0.820 \pm 0.048$ & $0.960 \pm 0.079$ \\
Sorafenib & $3.540 \pm 0.175$ & $1.280 \pm 0.144$ & $1.780 \pm 0.156$ \\
& ND & $0.814 \pm 0.071$ & $0.910 \pm 0.094$
\end{tabular}

${ }_{1}$ Percent inhibition values are the mean \pm S.D. of two separate experiments. Most potent values are bold.

With respect to the ethylamine linker containing $12 \mathbf{a}-\mathbf{g}$, concerning wild type BRAF, 12e showed the lowest $\mathrm{IC}_{50}$ with mean value $1.25 \mu \mathrm{M}$, followed by $12 \mathrm{c}$ and $\mathbf{1 2 b}$ with $\mathrm{IC}_{50} 1.38$ and $1.51 \mu \mathrm{M}$, respectively. $\mathbf{1 2} \mathrm{g}$ exhibited comparable activity to $\mathbf{1 2 b}$ with $\mathrm{IC}_{50}$ $1.53 \mu \mathrm{M}$. 12d showed the lowest activity among the halogenated $\mathbf{1 2 b}-\mathbf{d}$ with $\mathrm{IC}_{50} 1.79 \mu \mathrm{M}$. 12a showed the lowest activity with $\mathrm{IC}_{50} 3.25 \mu \mathrm{M}$. Regarding V600EBRAF, 12e had the highest activity with $\mathrm{IC}_{50} 0.62 \mu \mathrm{M}$, followed by $\mathbf{1 2 b}$ and $12 \mathrm{~g}$ with $\mathrm{IC}_{50} 0.74 \mu \mathrm{M}$ and $0.79 \mu \mathrm{M}$, respectively. 12a had the lowest activity with $\mathrm{IC}_{50} 1.91 \mu \mathrm{M}$. Concerning CRAF, 11e exhibited the highest activity with $\mathrm{IC}_{50} 1.14 \mu \mathrm{M}$, followed by $12 \mathrm{~g}$ and $12 \mathrm{c}$ with $\mathrm{IC}_{50} 1.48 \mu \mathrm{M}$ and $1.49 \mu \mathrm{M}$, respectively. On the other hand, 12a and $\mathbf{1 2 d}$ exhibited the lowest activities with $\mathrm{IC}_{50} 2.10 \mu \mathrm{M}$ and $2.98 \mu \mathrm{M}$, respectively.

Regarding the propylamine linker containing $\mathbf{1 2 h}-\mathbf{n}$ against wild type BRAF, 121 had the highest activity with $\mathrm{IC}_{50} 0.94 \mu \mathrm{M}$, followed by $\mathbf{1 2} \mathbf{j}, \mathbf{1 2} \mathbf{i}, \mathbf{1 2} \mathbf{m}$ and $\mathbf{1 2 k}$ with $\mathrm{IC}_{50} 1.13 \mu \mathrm{M}$, $1.33 \mu \mathrm{M}, 1.46 \mu \mathrm{M}$ and $1.53 \mu \mathrm{M}$, respectively. 12h (unsubstituted) and 12n (naphthyl) exhibited the lowest activity with $\mathrm{IC}_{50} 2.32 \mu \mathrm{M}$ and $3.54 \mu \mathrm{M}$, respectively. Concerning V600EBRAF, 121 showed the highest activity with $\mathrm{IC}_{50} 0.49 \mu \mathrm{M}$, followed by $\mathbf{1 2} \mathbf{i}$ and $\mathbf{1 2} \mathbf{j}$ with $\mathrm{IC}_{50} 0.53 \mu \mathrm{M}$ and $0.79 \mu \mathrm{M}$, respectively. 12k and $\mathbf{1 2} \mathrm{m}$ exhibited similar potency with $\mathrm{IC}_{50} 0.81 \mu \mathrm{M}$ and $0.82 \mu \mathrm{M}$, respectively. $12 \mathrm{n}$ showed the lowest activity with $\mathrm{IC}_{50} 1.28 \mu \mathrm{M}$. Finally, studying the activity of $\mathbf{1 2} \mathbf{h}-\mathbf{n}$ over CRAF revealed that $\mathbf{1 2 l}$ exhibited the highest activity with $\mathrm{IC}_{50} 0.84 \mu \mathrm{M} . \mathbf{1 2} \mathbf{i}, \mathbf{1 2} \mathbf{k}$ and $\mathbf{1 2}$ m showed almost similar potencies with $\mathrm{IC}_{50}$ 
$0.98 \mu \mathrm{M}, 0.99 \mu \mathrm{M}$ and $0.96 \mu \mathrm{M}$, respectively. 12h exhibited the lowest activity with $\mathrm{IC}_{50}$ $2.14 \mu \mathrm{M}$.

From the above-mentioned results, we can build a structure-activity relationship for the final compounds over the three RAF isoforms. Compounds that carry propylamine linker showed higher activity compared to their ethylamine analogues. Moreover, electron withdrawing groups such as flouro-, chloro-, and triflouromethyl groups enhanced the activity over electron-donating groups. Compounds containing bulky groups as bromo and naphthyl exhibited lower activity compared to those containing small groups as methyl and flouro. The optimum activity was obtained with the moderate size triflouro methyl and propylamine linker.

\subsubsection{In Vitro Antiproliferative Activity}

All target compounds were submitted to the NCI, USA, for in vitro antiproliferative assay over a 60-cell line panel representing nine different types of cancer (non-small cell lung cancer, leukemia, colon cancer, ovarian cancer, CNS cancer, melanoma, renal cancer, breast cancer, and prostate cancer) (Figure 2). In general, the compounds with ethylamine linker had the highest mean percent inhibition (Figure 2A). 12e exhibited the highest mean percent inhibition with a mean value of around $50 \%$, followed by $12 \mathrm{~g}$ and $12 \mathrm{~h}$ with mean percent inhibition of $30 \%$.

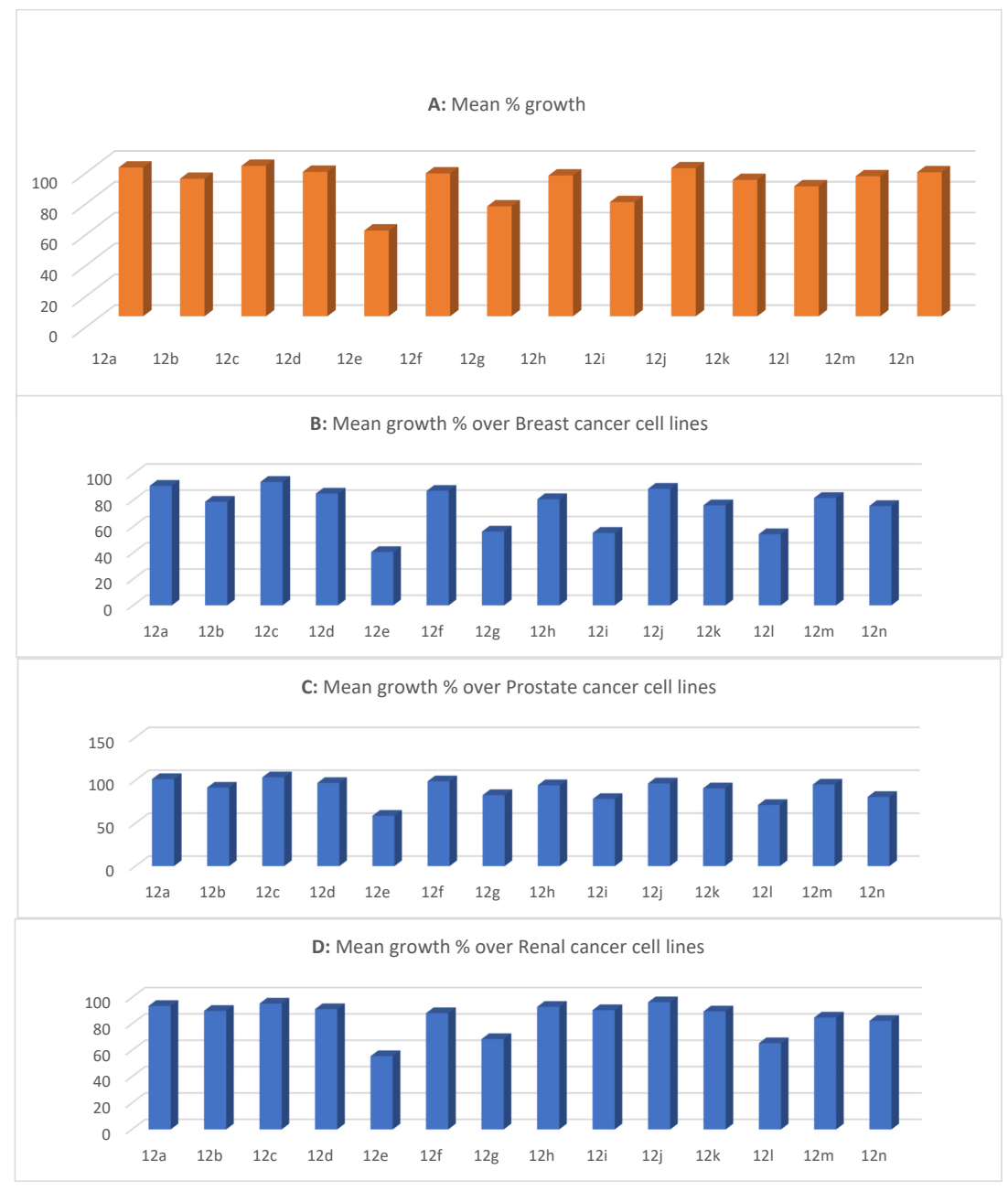

Figure 2. Cont. 
E: Mean groth \% over Ovarian cancer cells

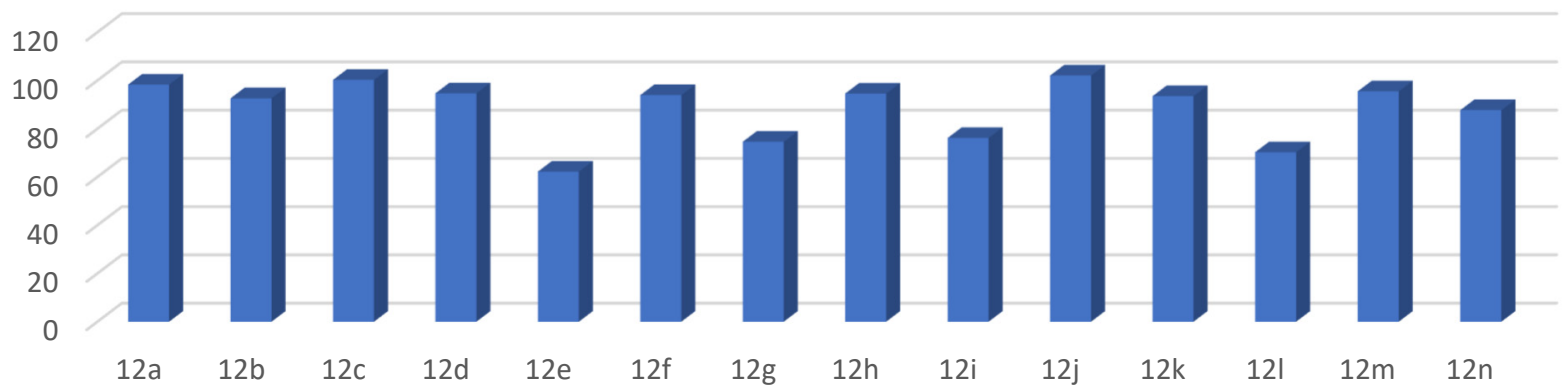

F: Mean growth \% over melanoma cell lines

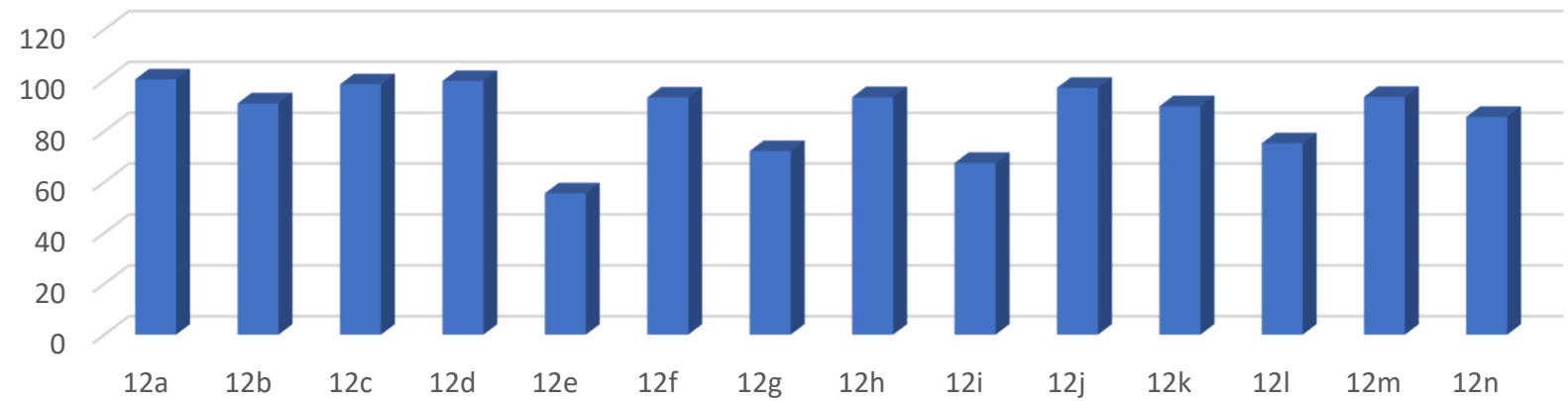

G: Mean growth \% over colon cancer cell lines

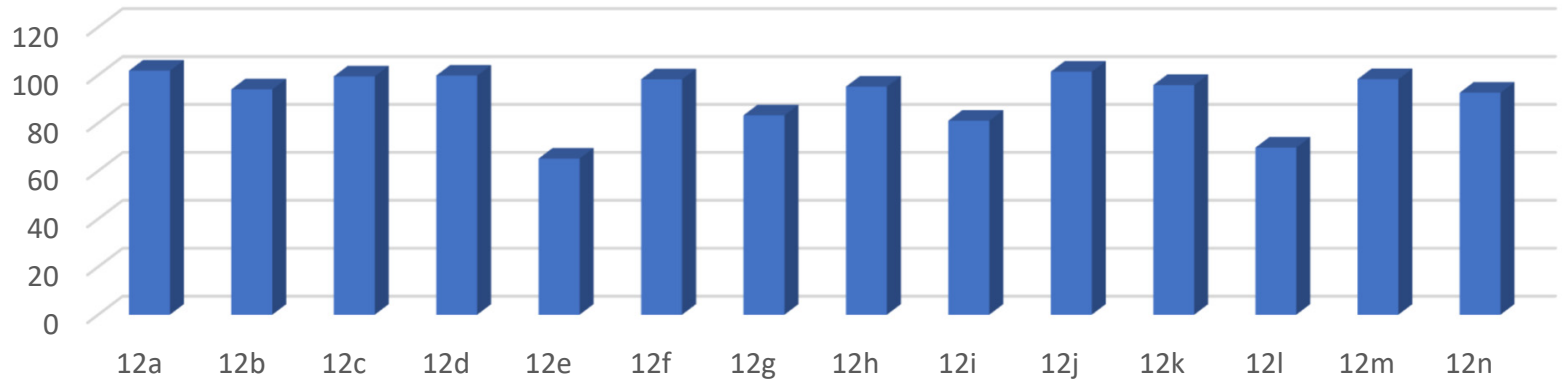

H: Mean growth \% over CNS cell lines

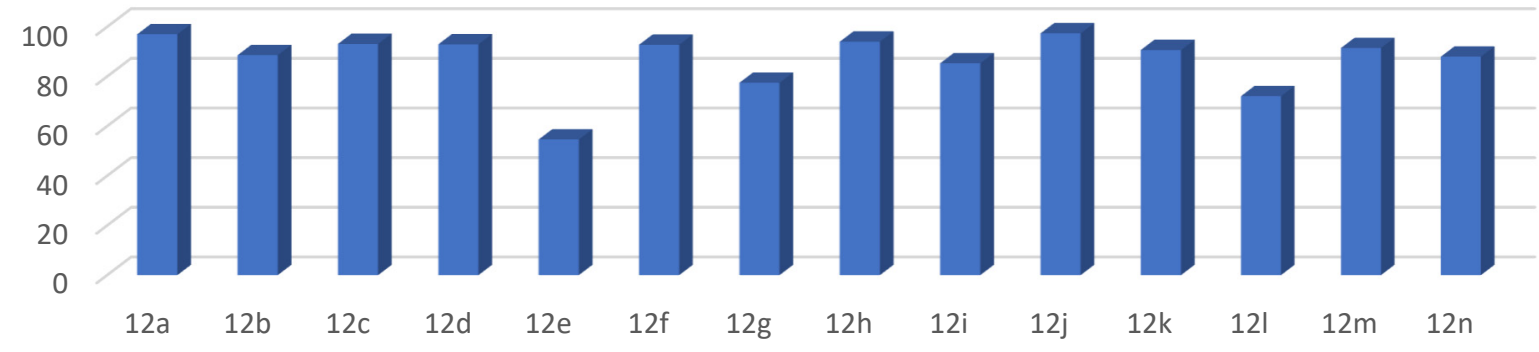

Figure 2. Cont. 


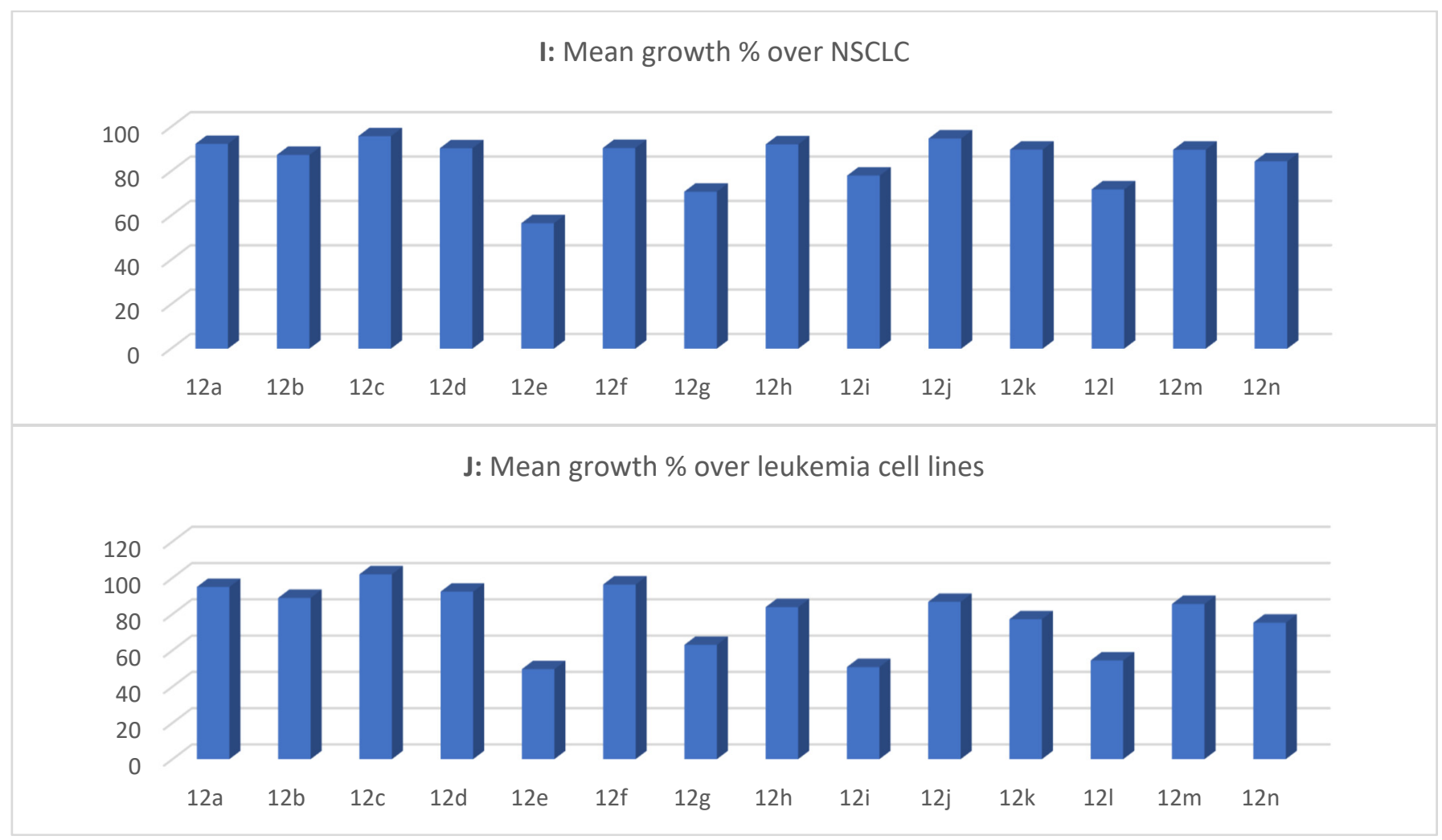

Figure 2. Effect of the target compounds 12a-n over NCI 60 cell lines. (A) Mean growth percentage over 60 cell lines. (B) Mean growth percentage over breast cancer cell lines. (C) Mean growth percentage over prostate cancer cell lines. (D) Mean growth percentage over renal cancer cell lines. (E) Mean growth percentage over ovarian cancer cell lines. (F) Mean growth percentage over melanoma cell lines. (G) Mean growth percentage over colon cancer cell lines. (H) Mean growth percentage over CNS cancer cell lines. (I) Mean growth percentage over NSCLC cell lines. (J) Mean growth percentage over leukemia cell lines. (See Tables S1 and S2 for detailed cell lines).

The sub-panel analysis of NCI data revealed that 12e showed the most significant growth inhibition over most of the tested cancer subtypes. Regarding leukemia cell lines, 12e, 12i and 121 possessed the highest activity ( $60 \%, 50 \%$ and $46 \%$ mean percent inhibition). Concerning non-small cell lung cancer cell lines, 12e showed 50\% mean percent inhibition, followed by $\mathbf{1 2} \mathrm{g}$ and $\mathbf{1 2 1}$, both with $30 \%$ mean percent inhibition. 12e and $\mathbf{1 2 1}$ were found to be the most active against colon cancer cell lines with $40 \%$ and $30 \%$ mean percent inhibition, respectively. 12e exhibited the same inhibitory activity over CNS and melanoma cancer cell lines with $50 \%$ mean percent inhibition. Concerning ovarian cancer cell lines, 12e showed the highest activity with $40 \%$ mean percent inhibition, followed by $\mathbf{1 2} \mathbf{g}, \mathbf{1 2} \mathbf{i}$ and 121 with mean percent inhibitions of around $25 \%$. 12e showed the highest inhibition over renal cancer cell lines with mean percent inhibition of $45 \%$, followed by $\mathbf{1 2} \mathrm{g}$ and $\mathbf{1 2 l}$ with mean percent inhibition around 30\%. Only 12e showed a significant inhibitory activity over prostate cancer cell lines with mean percent inhibition of $40 \%$, followed by $\mathbf{1 2}$, $\mathbf{1 2} \mathbf{i}$, $\mathbf{1 2 l}$ and 12n with mean percent inhibitions of around 20\%. Finally, 12e showed more than $60 \%$ inhibition over breast cancer cell lines, followed by $12 \mathrm{~g}, \mathbf{1 2 i}$ and 121 with mean percent inhibitions of around $40 \%$.

Map heat analysis of the target compounds 12a-n (Figures S1 and S2) for leukemia cell lines showed that 12e exhibited the highest inhibitory effect over MOLT-4, RPMI-8226, and SR with percent inhibitions of 55\%, 55\% and 65\%, respectively. $12 \mathrm{~g}$ showed around $45 \%$ inhibition over MOLT-4, RPMI-8226, and SR cell lines. 12i exhibited around 60\% inhibition over K-562, RPMI-8226, and SR. 12k showed 30\% inhibition over SR cell line. 121 and 12n showed around $60 \%$ and 30\% inhibition over K-562 and MOLT- 4 cell lines, respectively. Regarding non-small cell lung cancer, 12i showed around 30\% inhibition over 
EKVX, NCI-H226 and NCI-H522. 12e exhibited around $60 \%$ inhibition over EKVX cell line and 40\% inhibition over HOP-92, NCI-H23 and NCI-H460. 12g and 121 showed around $40 \%$ inhibition over HOP-92 and NCI-H226. Concerning colon cancer, 12e showed about $60 \%$ inhibition over HCT-116 and around 40\% inhibition over KM12 and HCT-15. 12i showed around 50\% inhibition over KM12. 121 exhibited more than 40\% over HCT-15 and HT29. Regarding CNS cancer cell lines, 12e showed more than 50\% inhibition over SF-295, SNB-75 and U251. In the case of melanoma cell lines, 12e, 12g, 12h, 12i, 12k, 12n and $12 \mathbf{l}$ showed $91 \%, 80 \%, 40 \%, 97 \%, 40 \%, 40 \%$ and $70 \%$ inhibition over SK-MEL-5, respectively. In the case of ovarian cancer cell lines, $\mathbf{1 2} \mathbf{e}$ and $\mathbf{1 2} \mathbf{i}$ showed the highest inhibitory activity over OVCAR-4 with 71\% and 56\% inhibition, respectively. 12e also exhibited good inhibitory activity over NCI/ADR-RES cell line with $45 \%$ inhibition. Regarding renal cancer cell lines, 12e showed around 60\% inhibition over UO-31, RXF 393 and CAKI-1 cell lines. 12g exhibited $48 \%$ inhibition over UO-31 cell line. 121 showed strong inhibitory effect over UO-31, RXF 393 and CAKI-1 with 46\%, 57\% and 49\% inhibition, respectively. 12e was the only compound to show significant inhibition on a prostate cancer cell line with 55\% inhibition over the PC-3 cell line. Finally, in the case of breast cancer, 12e exhibited 77\% and 74\% inhibition over T-47D and MDA-MB-468, respectively. 12g showed significant inhibitory effect on T-47D and MDA-MB-468 with percent inhibitions of 73\% and 49\%, respectively. 12h, 12i, 12k, 121 and 12n showed high inhibitory activity over T-47D with $55 \%, 75 \%, 55 \%, 84 \%$ and $56 \%$ inhibition, respectively.

\subsubsection{Cell Cycle Analysis}

The compound 12e that possess a broad spectrum of activity over different cell lines was picked to study its consequences on cell cycle phases at a dose of $5 \mu \mathrm{M}$, the closest concentration to the $\mathrm{IC}_{50}(5.35 \mu \mathrm{M})$ of the compound $12 \mathrm{e}$ on the tested cell line on T-47D (one of the most sensitive cell lines to 12e) (Figure 3). The distribution of cell cycle was determined by flow cytometric assay after using propidium iodide to stain the DNA content of the treated cells. After $72 \mathrm{~h}$ of incubation, 12e showed an increase in the S-phase from $14 \%$ in the control cells to $18 \%$ in the treated cells, and it increased the G1 phase from $29 \%$ to $31 \%$. Meanwhile, the cells of the G2-phase decreased to $6 \%$ compared to $8 \%$ in the untreated cells. This indicates that the compound 12e prevents cancer cells from starting DNA division, which is characteristic for kinases inhibitors.
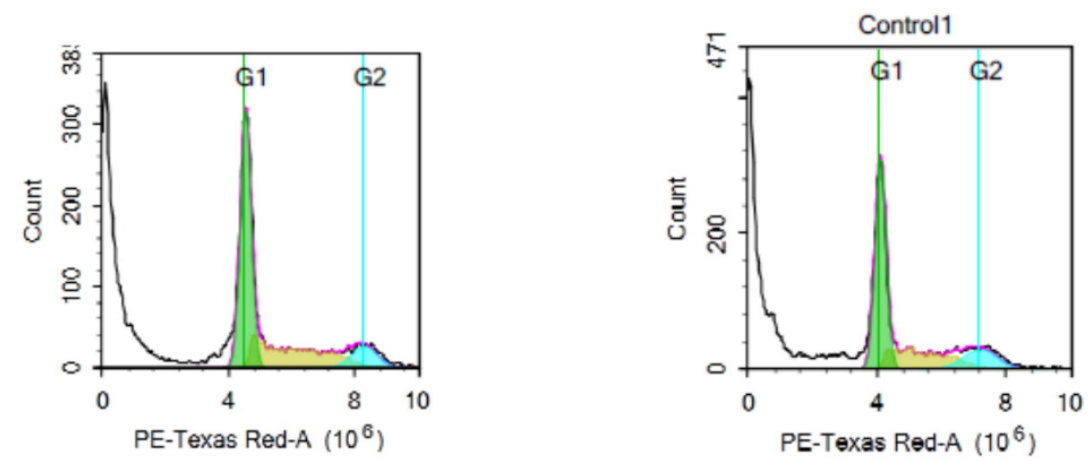

Figure 3. Cell cycle analysis of 12e on T-47D cell line (G1 (growth phase 1) in green, $\mathrm{S}$ phase (synthesis phase) in yellow, and G2 (growth phase 2) in light blue).

\subsection{Molecular Docking}

Molecular docking of 12e, 12i and 121 compounds and vemurafenib (reference ligand) in the binding site of the V600EBRAF protein was performed in order to study the differences in the binding modes of these compounds and in their interaction patterns with the amino acid residues of the protein.

The binding poses of these compounds, together with the $2 \mathrm{D}$ diagrams of their interaction with the amino acid residues of the V600EBRAF protein's binding site, are presented in Figure 4. The molecular docking studies demonstrated that the compounds 
$\mathbf{1 2} \mathbf{i}$ and vemurafenib have visibly different binding modes, both to each other and to the compounds $12 \mathrm{e}$ and 121.

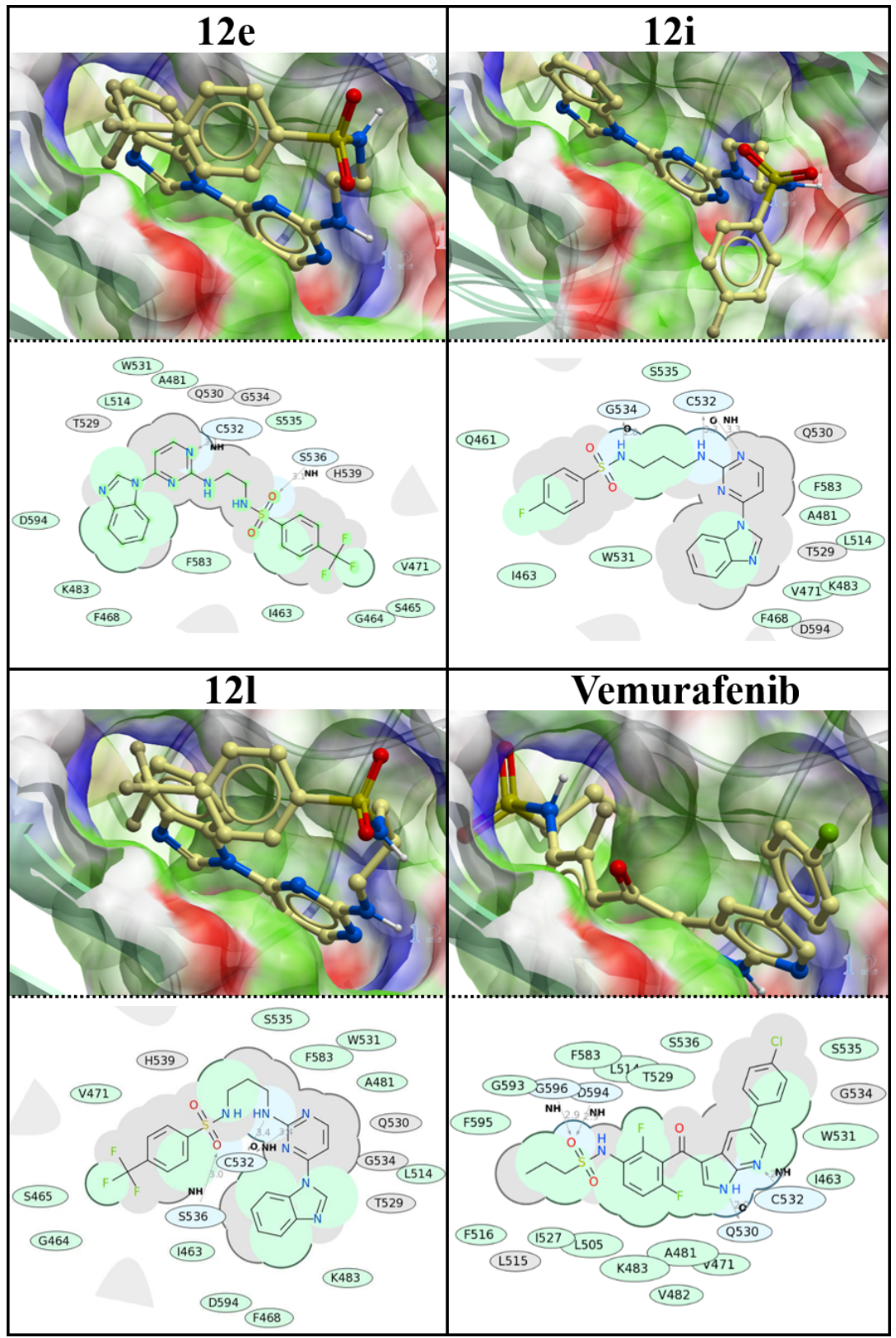

Figure 4. Binding poses of 12e, 12i, 121 and vemurafenib (reference ligand), and 2D diagrams of their interactions with the amino acid residues of V600EBRAF protein.

The compounds 12e, 12i, $\mathbf{1 2 l}$ and vemurafenib demonstrated the following docking mfScores: $-200.05,-164.08,-175.4$ and -213.07 , respectively. According to the results of the MMPBSA re-scoring of the obtained complexes, the compounds $\mathbf{1 2 e}, \mathbf{1 2} \mathbf{i}, \mathbf{1 2} \mathbf{1}$ and vemurafenib showed the following binding energies: $-23.66,-26.36,-25.86$ and $-31.41 \mathrm{kcal} / \mathrm{mol}$, respectively.

In terms of the results of the molecular docking studies, cysteine 532 amino acid residue of the V600EBRAF protein's binding site is of special importance for the interaction, since all three selected compounds and reference ligand showed hydrogen bonding formation with it (Figure 5). A481, F583, I463, K483, L514, S535, V471 and W531 are important for the hydrophobic interaction of the three selected compounds and vemurafenib with the V600EBRAF protein. Vemurafenib also forms three hydrogen bonds with the following 
amino acid residues: Q530, D594 and G596. The compounds 12e, 12i and $\mathbf{1 2 1}$ form additional hydrogen bonds with S536, G534 and S536, respectively. The compounds 12e and 12i both have additional hydrophobic interactions with D594, F468, G464 and S465, while the compound 12i has hydrophobic interaction with Q461 and also with F468. The reference ligand (vemurafenib) demonstrated unique hydrophobic interaction with F516, F595, G593, I527, L505, S536, T529 and V482.

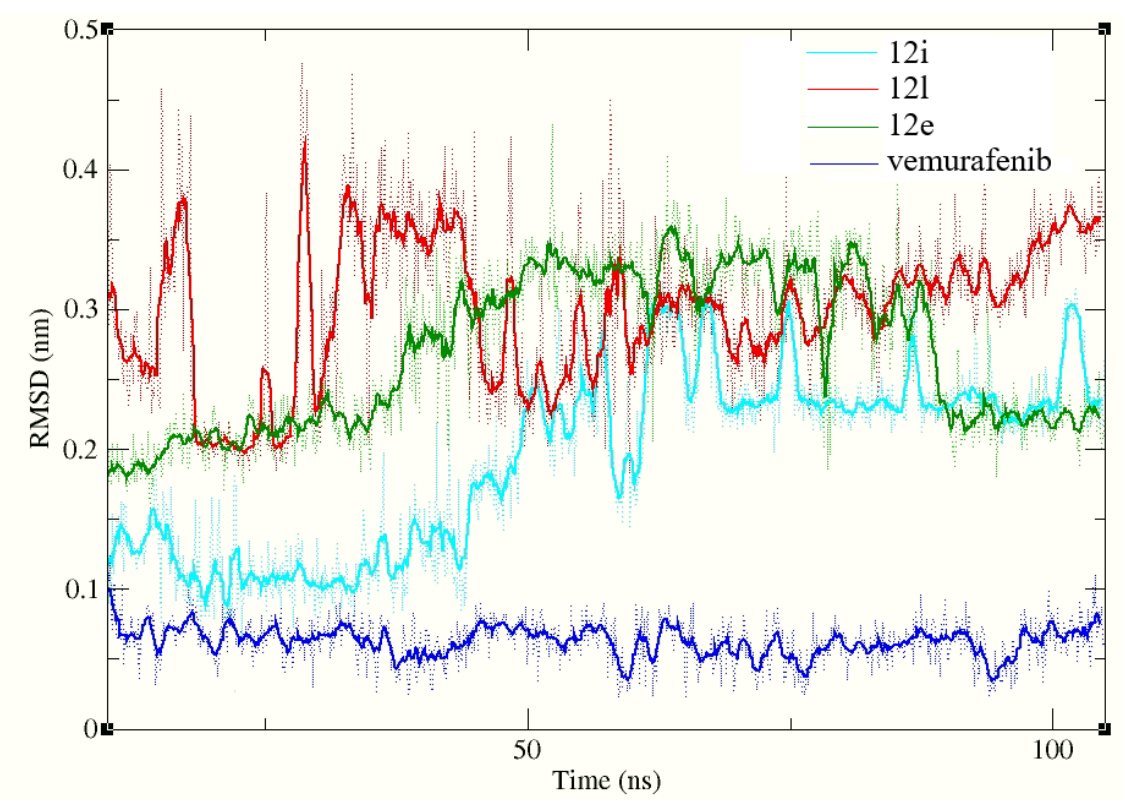

Figure 5. RMSD values of the 12i, 121 and 12 e compounds and vemurafenib during $100 \mathrm{~ns}$ of conventional molecular dynamics simulations (5-105 ns).

Molecular dynamics simulations of the interaction of the selected compounds with the V600EBRAF protein demonstrated that all four compounds maintained relative stability (RMSD values $<0.2 \mathrm{~nm}$, Figure 5), with the reference ligand (vemurafenib) being the most stable among the four studied compounds.

On the basis of both MMGBSA and MMPBSA calculations (Figure 6), we found that the reference ligand demonstrated the lowest values of binding energies ( -55 and -48 $\mathrm{kcal} / \mathrm{mol}$, respectively) among the four studied compounds. All of the three studied compounds showed very close values of binding energies against the binding site of the V600EBRAF protein, with the compound $\mathbf{1 2 1}$ having slightly lower binding energies and the compound 12e having slightly higher binding energies.

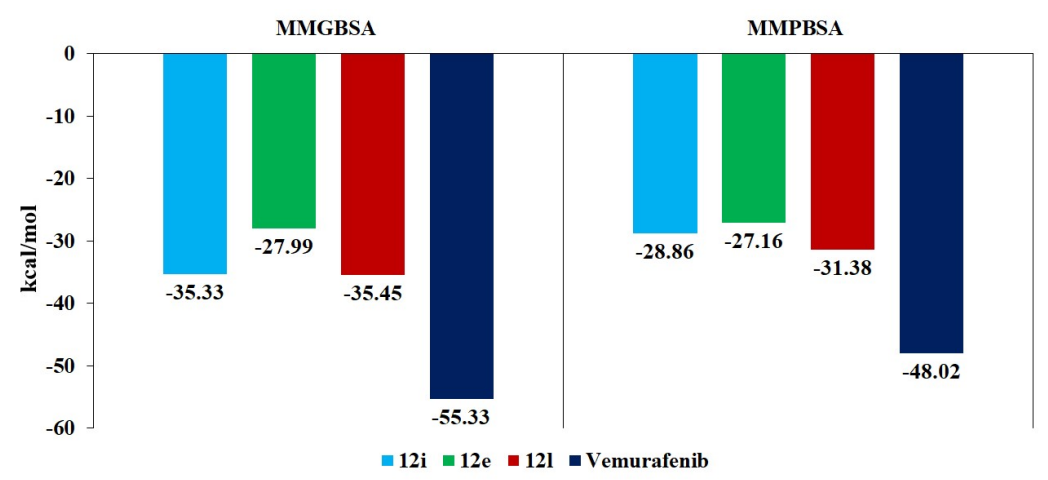

Figure 6. MMGBSA and MMPBSA binding energies as per the last 20 ns of molecular dynamics simulation of compounds 12i, 12e and $\mathbf{1 2 l}$ and reference ligand with the binding site of V6000EBRAF protein. 


\section{Conclusions}

A novel set of 4-(1H-benzo[ $d]$ imidazol-1-yl)pyrimidin-2-amine linked sulfonamide derivatives 12a-n was designed, synthesized, and tested over V600EBRAF. 12e, 12i and 121 exhibited the highest percent inhibitions at $1 \mu \mathrm{M}$ fixed concentration. They were further tested over wild-type BRAF, V600EBRAF and CRAF to detect their selectivity and potency. They showed higher activity toward V600EBRAF compared to wild-type BRAF and CRAF. 121 showed the dominant activity with an $\mathrm{IC}_{50}$ value over V600EBRAF of $0.49 \mu \mathrm{M}$, followed by $12 \mathbf{i}$ and $12 \mathrm{e}$ with $\mathrm{IC}_{50}$ of $0.53 \mu \mathrm{M}$ and $0.62 \mu \mathrm{M}$, respectively. They were tested over NCI 60 cell line panel, where 12e showed a wide range of activity against multiple cell lines. Heat map analysis revealed that the most sensitive cell line is SK-MEL-5, where 12l, 12i and 12e showed the highest activity on both SK-MEL-5 and A375 cell lines (Table 4). The cell cycle analysis of $\mathbf{1 2 e}$ showed an accumulation in both G1 and S phases.

Table 4. $\mathrm{IC}_{50}(\mu \mathrm{M})^{1}$ of the target compounds 12a-n over SK-MEL-5 and A375 cell lines.

\begin{tabular}{ccc}
\hline Comp. & SK-MEL-5 & A375 \\
\hline $\mathbf{1 2 a}$ & $20.45 \pm 0.86$ & $12.78 \pm 0.41$ \\
$\mathbf{1 2 b}$ & $15.63 \pm 0.37$ & $10.54 \pm 0.22$ \\
$\mathbf{1 2 c}$ & $17.58 \pm 0.49$ & $10.95 \pm 0.36$ \\
$\mathbf{1 2 d}$ & $19.67 \pm 0.51$ & $11.78 \pm 0.71$ \\
$\mathbf{1 2} \mathbf{c}$ & $6.54 \pm 0.18$ & $\mathbf{2 . 8 9} \pm \mathbf{0 . 1 4}$ \\
$\mathbf{1 2 f}$ & $18.74 \pm 0.69$ & $12.59 \pm 0.44$ \\
$\mathbf{1 2} \mathbf{1}$ & $8.25 \pm 0.12$ & $7.22 \pm 0.23$ \\
$\mathbf{1 2 h}$ & $11.28 \pm 0.29$ & $9.26 \pm 0.16$ \\
$\mathbf{1 2 i}$ & $\mathbf{2 . 3 6} \pm \mathbf{0 . 2 1}$ & $\mathbf{1 . 9 5} \pm \mathbf{0 . 1 3}$ \\
$\mathbf{1 2 j}$ & $12.88 \pm 0.72$ & $10.39 \pm 0.24$ \\
$\mathbf{1 2 k}$ & $13.46 \pm 0.39$ & $11.98 \pm 0.47$ \\
$\mathbf{1 2}$ & $\mathbf{2 . 0 2} \pm \mathbf{0 . 0 9}$ & $\mathbf{1 . 8 5} \pm \mathbf{0 . 1 1}$ \\
$\mathbf{1 2 m}$ & $14.56 \pm 0.71$ & $13.13 \pm 0.27$ \\
$\mathbf{1 2 n}$ & $17.85 \pm 0.62$ & $16.87 \pm 0.81$ \\
Sorafenib & $9.22 \pm 0.81$ & $5.25 \pm 0.74$ \\
\hline
\end{tabular}

${ }^{1}$ Percent inhibition values are presented as the mean \pm S.D. of two experiments. Most potent values are bold.

\section{Materials and Methods}

\subsection{Chemistry}

Electrothermal Capillary apparatus (Staffordshire, UK) was used to detect all melting points. NMR spectral analyses were performed using a Bruker Avance 300 or 400 spectrometer ((Bruker Bioscience, Billerica, MA, USA) using TMS as standard, and chemical shift values were recorded in ppm. LC-MS analysis was performed using a Waters 3100 mass detector (Milford, USA), Waters 2998 photodiode array detector, Waters SFO system fluidics organizer, Waters 2545 binary gradient module, Waters reagent manager, Waters 2767 sample manager and Sunfire ${ }^{\mathrm{TM}} \mathrm{C} 18$ column $(4.6 \times 50 \mathrm{~mm}, 5 \mu \mathrm{m}$ particle size $)$; solvent gradient $=95 \% \mathrm{~A}$ at $0 \mathrm{~min}, 1 \% \mathrm{~A}$ at $5 \mathrm{~min}$; solvent $\mathrm{A}: 0.035 \%$ trifluoroacetic acid in deionized water; solvent B: $0.035 \%$ trifluoroacetic acid in methanol; FR $=3.0 \mathrm{~mL} / \mathrm{min}$. The AUC was calculated using Waters MassLynx 4.1 software. All reagents and solvents were purchased from Aldrich chemical Co. and Tokyo Chemical Industry (TCI) Co., and used without further purification.

\subsubsection{Synthesis of $1 \mathrm{H}-$ benzo[d]imidazole (2)}

It was synthesized from o-phenylenediamine according to reported procedure [50].

\subsubsection{Synthesis of 1-(2-(methylthio)pyrimidin-4-yl)-1H-benzo[d]imidazole (3)}

To a solution of $2(10.1 \mathrm{~g}, 84.8 \mathrm{mmol})$ in DMF $(30 \mathrm{~mL})$, we added sodium hydride ( $6.00 \mathrm{~g}$ of a $60 \%$ suspension in mineral oil, $90.1 \mathrm{mmol}$ ) under $\mathrm{N}_{2}$ atmosphere and stirred the mixture for $1 \mathrm{~h}$. 4-Chloro-2-(methylthio)pyrimidine (16 g, $99.4 \mathrm{mmol})$ in DMF was 
slowly added, and the reaction mixture was stirred for an additional $12 \mathrm{~h}$ at $80{ }^{\circ} \mathrm{C}$, before being terminated with $10 \% \mathrm{NaHCO}_{3}$, followed by extraction with methylene chloride. The organic layer was washed with water and dried using $\mathrm{Na}_{2} \mathrm{SO}_{4}$. The solvent was removed under reduced pressure to afford 3 as viscous oil $(77 \%) ;{ }^{1} \mathrm{H}-\mathrm{NMR}\left(400 \mathrm{MHz}, \mathrm{DMSO}-d_{6}\right)$ $\delta 9.13(\mathrm{~s}, 1 \mathrm{H}), 8.73(\mathrm{~d}, 1 \mathrm{H}, J=5.5 \mathrm{~Hz}), 8.41(\mathrm{~d}, 1 \mathrm{H}, J=8.0 \mathrm{~Hz}), 7.76(\mathrm{~d}, 2 \mathrm{H}, J=5.5 \mathrm{~Hz})$, 7.45-7.35 (m, 2H), $2.64(\mathrm{~s}, 3 \mathrm{H}) .{ }^{13} \mathrm{C}-\mathrm{NMR}\left(100 \mathrm{MHz}, \mathrm{DMSO}-d_{6}\right) \delta 172.7,159.8,156.5,144.9$, $142.7,131.7,125.1,124.4,120.6,115.6,107.7,105.6,14.3$. LC-MS $(m / z)$ for $\mathrm{C}_{12} \mathrm{H}_{10} \mathrm{~N}_{4} \mathrm{~S}: 242.06$, found: $243.11(\mathrm{M}+1)^{+}$.

\subsubsection{Synthesis of 1-(2-(methyl sulfonyl) pyrimidin-4-yl)-1H-benzo[d]imidazole (4)}

A solution of potassium peroxymonosulfate $(84.5 \mathrm{~g}, 124 \mathrm{mmol})$ in water $(150 \mathrm{~mL})$ was added dropwise to a methanolic solution of compound $3(10.2 \mathrm{~g}, 41.3 \mathrm{mmol})$ in methanol $(120 \mathrm{~mL})$ at 25 degrees and stirred for an additional $48 \mathrm{~h}$. The mixture was reduced by removing methanolusing reduced pressure and extracted with methylene chloride (20mL). The organic layer was dried using $\mathrm{Na}_{2} \mathrm{SO}_{4}$ and evaporated under reduced pressure. The residue was purified by column chromatography (hexane/ethyl acetate, 2:1) to give 4 as a white solid (81\%), m.p.: $180-182{ }^{\circ} \mathrm{C} .{ }^{1} \mathrm{H}-\mathrm{NMR}\left(300 \mathrm{MHz}, \mathrm{DMSO}-d_{6}\right) \delta 9.35(\mathrm{~d}, 1 \mathrm{H}$, $J=6.0 \mathrm{~Hz}), 9.25(\mathrm{~d}, 1 \mathrm{H}, J=3.0 \mathrm{~Hz}), 8.52(\mathrm{~d}, 1 \mathrm{H}, J=9.0 \mathrm{~Hz}),, 8.01(\mathrm{~d}, 1 \mathrm{H}, J=6.0 \mathrm{~Hz}), 7.82$ $(\mathrm{d}, 1 \mathrm{H}, J=9.0 \mathrm{~Hz}),, 7.53-7.39(\mathrm{~m}, 2 \mathrm{H}), 3.55(\mathrm{~s}, 3 \mathrm{H}) .{ }^{13} \mathrm{C}-\mathrm{NMR}\left(75 \mathrm{MHz}, \mathrm{DMSO}-d_{6}\right) \delta .166 .8$, $164.1,156.6,145.0,142.8,131.7,125.4,124.6,120.7,115.8,113.9,39.9$. LC-MS $(m / z)$ for $\mathrm{C}_{12} \mathrm{H}_{10} \mathrm{~N}_{4} \mathrm{O}_{2}$ S: 274.05, found: $275.10 ;(\mathrm{M}+1)^{+}$.

\subsubsection{Synthesis of Sustituted Ethanediamine and Propanediamine (11a-n)}

Synthesis of side chains 11a-n was carried out according to the reported literature [48].

\subsubsection{Synthesis of Target Compounds (12a-n)}

To a solution of compound $4(0.37 \mathrm{mmol})$ in DMSO $(5.0 \mathrm{~mL})$, DIPEA $(0.6 \mathrm{~g}, 3.6 \mathrm{mmol})$ and 11a-n $(0.55 \mathrm{mmol})$ were added. The mixture was heated at $90{ }^{\circ} \mathrm{C}$ and stirred for $8 \mathrm{~h}$; then, the mixture was partitioned between ethyl acetate and water. The organic layer was dried using $\mathrm{Na}_{2} \mathrm{SO}_{4}$ and evaporated. The residue was purified by column chromatography (hexane/ethyl acetate, 2:1) to yield the desired products.

$N$-(2-((4-(1H-benzo [d]imidazol-1-yl) pyrimidin-2-yl) amino)ethyl)benzenesulfonamide (12a): buff solid, (71\%), m.p. 78-80 ${ }^{\circ} \mathrm{C} .{ }^{1} \mathrm{H}-\mathrm{NMR}\left(400 \mathrm{MHz}, \mathrm{CD}_{3} \mathrm{OD}\right) \delta 9.05$ (s, 1H), 8.55 (d, $1 \mathrm{H}, J=7.5 \mathrm{~Hz}), 8.08(\mathrm{~s}, 1 \mathrm{H}), 7.86-7.81(\mathrm{~m}, 3 \mathrm{H}), 7.72(\mathrm{~d}, 1 \mathrm{H}, J=7.5 \mathrm{~Hz}), 7.63-7.48(\mathrm{~m}, 4 \mathrm{H})$, $7.41-7.35(\mathrm{~m}, 2 \mathrm{H}), 6.36(\mathrm{~d}, 1 \mathrm{H}, J=6.0 \mathrm{~Hz}), 3.62(\mathrm{~s}, 2 \mathrm{H}), 3.18(\mathrm{t}, J=6.5 \mathrm{~Hz}, 2 \mathrm{H}) .{ }^{13} \mathrm{C} \mathrm{NMR}(100$ $\left.\mathrm{MHz}, \mathrm{CD}_{3} \mathrm{OD}\right) \delta 155.6,143.7,142.0,140.4,132.3,132.2,131.7,128.9,128.8,126.53,126.49$, 124.6, 123.3, 118.8, 115.7. LC-MS $(m / z)$ for $\mathrm{C}_{19} \mathrm{H}_{18} \mathrm{~N}_{6} \mathrm{O}_{2} \mathrm{~S}: 394.12$, found: $395.21(\mathrm{M}+1)^{+}$.

$\mathrm{N}$-(2-((4-(1H-benzo [d]imidazol-1-yl) pyrimidin-2-yl) amino)ethyl)-4-fluorobenzene sulfonamide (12b): white solid (67\%), m.p. $74-76{ }^{\circ} \mathrm{C} .{ }^{1} \mathrm{H}-\mathrm{NMR}\left(400 \mathrm{MHz}, \mathrm{DMSO}-d_{6}\right) \delta 9.06$ $(\mathrm{s}, 1 \mathrm{H}), 8.50(\mathrm{~d}, 1 \mathrm{H}, J=7.5 \mathrm{~Hz}), 8.13(\mathrm{~d}, 1 \mathrm{H}, J=6.0 \mathrm{~Hz}), 7.96(\mathrm{~s}, 1 \mathrm{H}), 7.88-7.80(\mathrm{~m}, 2 \mathrm{H}), 7.76$ $(\mathrm{d}, 1 \mathrm{H}, J=7.5 \mathrm{~Hz}), 7.62-7.53(\mathrm{~m}, 1 \mathrm{H}), 7.41-7.31(\mathrm{~m}, 3 \mathrm{H}), 6.42(\mathrm{~d}, 1 \mathrm{H}, J=6.0 \mathrm{~Hz}), 3.54(\mathrm{~d}, 2 \mathrm{H}$, $J=5.5 \mathrm{~Hz}), 3.04(\mathrm{~s}, 2 \mathrm{H}),{ }^{13} \mathrm{C}-\mathrm{NMR}\left(100 \mathrm{MHz}, \mathrm{DMSO}-d_{6}\right) \delta 165.8,163.3,155.7,155.2,145.0$, $142.6,137.2,132.1,129.9,126.9,124.6,123.6,120.2,116.9,104.3,41.9,40.7$. LC-MS $(\mathrm{m} / z)$ for $\mathrm{C}_{19} \mathrm{H}_{17} \mathrm{FN}_{6} \mathrm{O}_{2} \mathrm{~S}: 412.11$, found: $413.21(\mathrm{M}+1)^{+}$.

N-(2-((4-(1H-benzo [d]imidazol-1-yl) pyrimidin-2-yl) amino)ethyl)-4-chlorobenzene sulfonamide (12c): light yellow solid (77\%), m.p. 82-84 ${ }^{\circ} \mathrm{C} .{ }^{1} \mathrm{H}-\mathrm{NMR}\left(400 \mathrm{MHz}, \mathrm{DMSO}-d_{6}\right)$ $\delta 9.05(\mathrm{~s}, 1 \mathrm{H}), 8.55(\mathrm{~d}, 1 \mathrm{H}, J=7.5 \mathrm{~Hz}), 8.08(\mathrm{~d}, 1 \mathrm{H}, J=3.5 \mathrm{~Hz}), 7.75(\mathrm{~d}, 1 \mathrm{H}, J=7.5 \mathrm{~Hz})$, 7.65-7.44 (m, 6H), 7.42-7.34 (m, 2H), $6.72(\mathrm{~d}, 1 \mathrm{H}, J=6.0 \mathrm{~Hz}), 3.63(\mathrm{~s}, 2 \mathrm{H}), 3.18(\mathrm{t}, 2 \mathrm{H}, J=6.5$ Hz). ${ }^{13} \mathrm{C}-\mathrm{NMR}\left(100 \mathrm{MHz}, \mathrm{DMSO}-d_{6}\right) \delta 155.6,143.7,142.0,140.4,132.3,132.2,131.7,128.9$, $126.6,124.3,123.3,118.8,115.7,41.4,40.4$. LC-MS $(m / z)$ for $\mathrm{C}_{19} \mathrm{H}_{17} \mathrm{ClN}_{6} \mathrm{O}_{2} \mathrm{~S}: 428.08$, found: $429.20(\mathrm{M}+1)^{+}$.

N-(2-((4-(1H-benzo [d]imidazol-1-yl) pyrimidin-2-yl) amino)ethyl)-4-bromobenzene sulfonamide (12d): light brown solid (70\%), m.p. 80-82 ${ }^{\circ} \mathrm{C} .{ }^{1} \mathrm{H}-\mathrm{NMR}\left(400 \mathrm{MHz}, \mathrm{DMSO}-d_{6}\right)$ $\delta 9.07(\mathrm{~s}, 1 \mathrm{H}), 8.51(\mathrm{~d}, 1 \mathrm{H}, J=8.0 \mathrm{~Hz}), 8.12(\mathrm{~d}, 1 \mathrm{H}, J=6.0 \mathrm{~Hz}), 7.97(\mathrm{~s}, 1 \mathrm{H}$, replaceable), 
$7.91(\mathrm{~s}, 1 \mathrm{H}), 7.82(\mathrm{~d}, 2 \mathrm{H}, J=6.5 \mathrm{~Hz}), 7.77-7.73(\mathrm{~m}, 3 \mathrm{H}), 7.61-7.55(\mathrm{~m}, 3 \mathrm{H}), 7.37-7.31(\mathrm{~m}$, $1 \mathrm{H}), 6.43(\mathrm{~d}, 1 \mathrm{H}, J=6.0 \mathrm{~Hz}), 3.55(\mathrm{~d}, 2 \mathrm{H}, J=6.0 \mathrm{~Hz}), 3.03(\mathrm{~d}, 2 \mathrm{H}, J=5.5 \mathrm{~Hz}) .{ }^{13} \mathrm{C} \mathrm{NMR}$ $\left(100 \mathrm{MH}, \mathrm{DMSO}-d_{6}\right) \delta 163.3,155.8,155.2,145.0,142.6,140.6,132.9,132.1,129.7,126.9,124.6$, 123.6, 120.2, 116.0, 104.3, 42.6, 42.0. LC-MS (m/z) for $\mathrm{C}_{19} \mathrm{H}_{17} \mathrm{BrN}_{6} \mathrm{O}_{2} \mathrm{~S}: 472.03$, found: 473.10 $(\mathrm{M}+1)^{+}$.

N-(2-((4-(1H-benzo [d]imidazol-1-yl) pyrimidin-2-yl) amino)ethyl)-4-(trifluoromethyl) benzenesulfonamide (12e): white solid (62\%), m.p. 70-72 ${ }^{\circ} \mathrm{C} .{ }^{1} \mathrm{H}-\mathrm{NMR}\left(400 \mathrm{MHz}, \mathrm{CD}_{3} \mathrm{OD}\right)$ $\delta 9.02(\mathrm{~s}, 1 \mathrm{H}), 8.55(\mathrm{~d}, 1 \mathrm{H}, J=7.5 \mathrm{~Hz}), 8.06-7.99(\mathrm{~m}, 4 \mathrm{H}), 7.90(\mathrm{~d}, 2 \mathrm{H}, J=8.0 \mathrm{~Hz}), 7.84(\mathrm{~d}$, $2 \mathrm{H}, J=7.0 \mathrm{~Hz}), 7.72(\mathrm{~d}, 1 \mathrm{H}, J=7.5 \mathrm{~Hz}), 7.41-7.32(\mathrm{~m}, 2 \mathrm{H}), 6.33(\mathrm{~d}, 1 \mathrm{H}, J=6.0 \mathrm{~Hz}), 3.56(\mathrm{~s}$, 2H), $3.26(\mathrm{~d}, 2 \mathrm{H}, J=7.0 \mathrm{~Hz}) .{ }^{13} \mathrm{C}-\mathrm{NMR}\left(100 \mathrm{MHz}, \mathrm{CD}_{3} \mathrm{OD}\right) \delta 162.6,155.6,144.4,143.6$, $141.9,133.4,131.7,127.4,126.0,124.9,124.3,123.3,118.8,115.7,40.2,34.8$. LC-MS $(\mathrm{m} / z)$ for $\mathrm{C}_{20} \mathrm{H}_{17} \mathrm{~F}_{3} \mathrm{~N}_{6} \mathrm{O}_{2} \mathrm{~S}: 462.10$, found: $463.10(\mathrm{M}+1)^{+}$.

N-(2-((4-(1H-benzo [d]imidazol-1-yl) pyrimidin-2-yl) amino)ethyl)-4-methoxy benzenesulfonamide (12f): white solid (81\%), m.p. 64-66 ${ }^{\circ} \mathrm{C},{ }^{1} \mathrm{H}-\mathrm{NMR}\left(400 \mathrm{MHz}, \mathrm{DMSO}-d_{6}\right)$ $\delta 9.06(\mathrm{~s}, 1 \mathrm{H}), 8.50(\mathrm{~d}, 1 \mathrm{H}, J=7.5 \mathrm{~Hz}), 8.12(\mathrm{~d}, 1 \mathrm{H}, J=5.0 \mathrm{~Hz}), 7.94(\mathrm{~s}, 1 \mathrm{H}), 7.77-7.72(\mathrm{~m}$, $4 \mathrm{H}), 7.41-7.31(\mathrm{~m}, 2 \mathrm{H}), 7.03(\mathrm{~d}, 2 \mathrm{H}, J=8.0 \mathrm{~Hz}), 6.42(\mathrm{~d}, 1 \mathrm{H}, J=6.0 \mathrm{~Hz}), 3.77(\mathrm{~s}, 3 \mathrm{H}), 3.44$ $(\mathrm{d}, 2 \mathrm{H}, J=4.0 \mathrm{~Hz}), 3.00$ (s, 2H). ${ }^{13} \mathrm{C}-\mathrm{NMR}\left(100 \mathrm{MHz}, \mathrm{DMSO}-d_{6}\right) \delta .162 .4,155.8,154.9,144.7$, $142.6,132.4,132.1,129.1,124.6,123.2,119.9,114.7,104.3,56.2,42.1,41.0$. LC-MS (m/z) for $\mathrm{C}_{20} \mathrm{H}_{20} \mathrm{~N}_{6} \mathrm{O}_{3} \mathrm{~S}: 424.13$, found: $425.20(\mathrm{M}+1)^{+}$.

N-(2-((4-(1H-benzo [d]imidazol-1-yl) pyrimidin-2-yl) amino) ethyl)-4-methyl benzenesulfonamide (12g): yellow solid (52\%), m.p. 66-68 ${ }^{\circ} \mathrm{C} .{ }^{1} \mathrm{H}-\mathrm{NMR}\left(400 \mathrm{MHz}, \mathrm{CD}_{3} \mathrm{OD}\right) \delta 9.02$ $(\mathrm{s}, 1 \mathrm{H}), 8.52(\mathrm{~d} 1 \mathrm{H}, 7.0 \mathrm{~Hz}), 8.06(\mathrm{~s}, 1 \mathrm{H}), 7.80-7.69(\mathrm{~m}, 4 \mathrm{H}), 7.41-7.33(\mathrm{~m}, 3 \mathrm{H}), 7.23(\mathrm{~d}, 2 \mathrm{H}, J=$ $8.0 \mathrm{~Hz}), 6.33(\mathrm{~d}, 1 \mathrm{H}, J=6.0 \mathrm{~Hz}), 3.59(\mathrm{~s}, 2 \mathrm{H}), 3.17(\mathrm{t}, 2 \mathrm{H}, J=6.5 \mathrm{~Hz}), 2.29(\mathrm{~s}, 3 \mathrm{H}) .{ }^{13} \mathrm{C} \mathrm{NMR}$

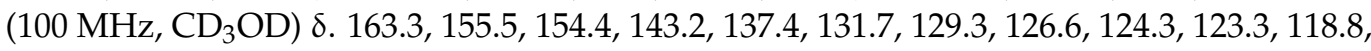
115.7, 44.7, 41.4, 20.0. LC-MS $(m / z)$ for $\mathrm{C}_{20} \mathrm{H}_{20} \mathrm{~N}_{6} \mathrm{O}_{2} \mathrm{~S}: 408.13$, found: $409.18(\mathrm{M}+1)^{+}$.

$\mathrm{N}$-(3-((4-(1H-benzo [d]imidazol-1-yl) pyrimidin-2-yl) amino)propyl)benzenesulfonamide (12h): yellow solid (64\%), m.p. $75-77^{\circ} \mathrm{C},{ }^{1} \mathrm{H}-\mathrm{NMR}\left(400 \mathrm{MHz}, \mathrm{DMSO}-d_{6}\right) \delta 9.05$ (s, 1H), $8.52(\mathrm{~d}, 1 \mathrm{H}, J=7.5 \mathrm{~Hz}), 8.10(\mathrm{~d}, 1 \mathrm{H}, J=5.0 \mathrm{~Hz}), 7.90(\mathrm{~s}, 1 \mathrm{H}), 7.81-7.77(\mathrm{~m}, 4 \mathrm{H}), 7.63-7.60$ $(\mathrm{m}, 3 \mathrm{H}), 7.40-7.32(\mathrm{~m}, 2 \mathrm{H}), 6.41(\mathrm{~d}, 1 \mathrm{H}, \mathrm{J}=5.5 \mathrm{~Hz}), 3.07(\mathrm{~d}, 2 \mathrm{H}, J=6.0 \mathrm{~Hz}), 2.76(\mathrm{t}, 2 \mathrm{H}, J=$ $7.0 \mathrm{~Hz}), 1.54(\mathrm{t}, 2 \mathrm{H}, J=7.0 \mathrm{~Hz}) .{ }^{13} \mathrm{C}-\mathrm{NMR}\left(100 \mathrm{MHz}, \mathrm{DMSO}-d_{6}\right) \delta 163.3,161.5,155.8,155.0$, 145.0, 142.6, 140.9, 132.8, 132.2, 129.7, 126.9, 124.5, 123.5, 120.2, 116.0, 104.1, 38.2, 35.1, 29.7. LC-MS (m/z) for $\mathrm{C}_{20} \mathrm{H}_{20} \mathrm{~N}_{6} \mathrm{O}_{2} \mathrm{~S}: 408.13$, found: $409.20(\mathrm{M}+1)^{+}$.

$N$-(3-((4-(1H-benzo [d]imidazol-1-yl) pyrimidin-2-yl) amino)propyl)-4-fluorobenzene sulfonamide (12i): white solid, Yield 59\%, mp 80-82 ${ }^{\circ} \mathrm{C},{ }^{1} \mathrm{H}$ NMR (400 MHz, DMSO- $\left.d_{6}\right)$ $\delta 9.05(\mathrm{~s}, 1 \mathrm{H}), 8.52(\mathrm{~d}, 1 \mathrm{H}, J=7.24 \mathrm{~Hz}), 8.11(\mathrm{~d}, 1 \mathrm{H}, J=4.88 \mathrm{~Hz}), 7.83(\mathrm{~s}, 3 \mathrm{H}), 7.76(\mathrm{~d}, 2 \mathrm{H}, J$ $=7.56 \mathrm{~Hz}), 7.40-7.32(\mathrm{~m}, 4 \mathrm{H}), 6.41(\mathrm{~d}, 1 \mathrm{H}, J=5.76 \mathrm{~Hz}), 3.46(\mathrm{~d}, 2 \mathrm{H}, J=4.16 \mathrm{~Hz}), 2.90(\mathrm{~d}$, $2 \mathrm{H}, \mathrm{J}=6.16 \mathrm{~Hz}), 1.76(\mathrm{~d}, 2 \mathrm{H}, J=7.24 \mathrm{~Hz}) .{ }^{13} \mathrm{C}$ NMR $\left(100 \mathrm{MHz}, \mathrm{DMSO}-d_{6}\right) \delta 163.33,155.82$, 155.04, 144.97, 142.56, 137.25, 132.14, 129.93, 124.52, 123.53, 120.24, 116.82, 115.96, 104.05, 40.99 , 38.16, 29.17. LC-MS $(m / z)$ for $\mathrm{C}_{20} \mathrm{H}_{19} \mathrm{FN}_{6} \mathrm{O}_{2} \mathrm{~S}: 426.12$, found: $427.21(\mathrm{M}+1)^{+}$.

$\mathrm{N}$-(3-((4-(1H-benzo [d]imidazol-1-yl) pyrimidin-2-yl) amino)propyl)-4-chloro benzenesulfonamide (12j): viscous oil (59\%). ${ }^{1} \mathrm{H}-\mathrm{NMR}\left(400 \mathrm{MHz}, \mathrm{CD}_{3} \mathrm{OD}\right) \delta 9.04(\mathrm{~s}, 1 \mathrm{H}), 8.59$ (d, $1 \mathrm{H}, J=7.5 \mathrm{~Hz}), 8.08(\mathrm{~s}, 1 \mathrm{H}), 7.81(\mathrm{~d}, 2 \mathrm{H}, J=7.0 \mathrm{~Hz}), 7.74(\mathrm{~d}, 1 \mathrm{H}, J=7.5 \mathrm{~Hz}), 7.64-7.56(\mathrm{~m}$, $1 \mathrm{H}), 7.44-7.35(\mathrm{~m}, 4 \mathrm{H}), 7.37(\mathrm{~d}, 1 \mathrm{H}, J=6.0 \mathrm{~Hz}), 3.57(\mathrm{~s}, 2 \mathrm{H}), 3.02(\mathrm{t}, 2 \mathrm{H}, J=7.0 \mathrm{~Hz}), 1.85$ $(\mathrm{t}, 2 \mathrm{H}, J=7.0 \mathrm{~Hz}) .{ }^{13} \mathrm{C}-\mathrm{NMR}\left(100 \mathrm{MHz}, \mathrm{CD}_{3} \mathrm{OD}\right) \delta 164.6,157.8,155.9,143.7,141.4,140.3$, $131.9,128.9,126.8,124.7,123.3,118.6,116.1,112.9,103.7,42.6,40.4,28.9$. LC-MS $(\mathrm{m} / z)$ for $\mathrm{C}_{20} \mathrm{H}_{19} \mathrm{ClN}_{6} \mathrm{O}_{2} \mathrm{~S}: 442.09$, found: $443.20(\mathrm{M}+1)^{+}$.

$N$-(3-((4-(1H-benzo [d]imidazol-1-yl) pyrimidin-2-yl) amino)propyl)- 4-bromo benzenesulfonamide (12k): light brown solid (64\%), m.p. 90-92 ${ }^{\circ} \mathrm{C} .{ }^{1} \mathrm{H}-\mathrm{NMR}(400 \mathrm{MHz}$, DMSO-d $)_{6} \delta 9.05(\mathrm{~s}, 1 \mathrm{H}), 8.52(\mathrm{~d}, 1 \mathrm{H}, J=8.0 \mathrm{~Hz}), 8.10(\mathrm{~d}, 1 \mathrm{H}, J=6.0 \mathrm{~Hz}), 7.89(\mathrm{~s}, 1 \mathrm{H})$, 7.78-7.75 (m, 3H), $7.70(\mathrm{~s}, 1 \mathrm{H}), 7.758-7.49(\mathrm{~m}, 2 \mathrm{H}), 7.41-7.36(\mathrm{~m}, 2 \mathrm{H}), 6.40(\mathrm{~d}, 1 \mathrm{H}, J=6.0 \mathrm{~Hz})$, $3.46(\mathrm{~d}, 2 \mathrm{H}, J=6.0 \mathrm{~Hz}), 2.90(\mathrm{~d}, 2 \mathrm{H}, J=5.0 \mathrm{~Hz}), 1.74(\mathrm{t}, 2 \mathrm{H}, J=7.0 \mathrm{~Hz}) .{ }^{13} \mathrm{C}-\mathrm{NMR}$ $\left(100 \mathrm{MHz}, \mathrm{DMSO}-d_{6}\right) \delta 163.3,155.8,155.0,145.0,142.6,140.8,132.7,132.2,129.6,126.9,124.6$, $123.5,120.3,116.0,104.1,40.9,38.2,29.2$. LC-MS $(m / z)$ for $\mathrm{C}_{20} \mathrm{H}_{19} \mathrm{BrN}_{6} \mathrm{O}_{2} \mathrm{~S}: 486.04$, found: $487.20(\mathrm{M}+1)^{+}$. 
$N$-(3-((4-(1H-benzo [d]imidazol-1-yl) pyrimidin-2-yl) amino)propyl)-4-(trifluoromethyl) benzenesulfonamide (121): viscous oil (69\%). ${ }^{1} \mathrm{H}-\mathrm{NMR}\left(400 \mathrm{MHz}, \mathrm{CD}_{3} \mathrm{OD}\right) \delta 9.02(\mathrm{~s}, 1 \mathrm{H})$, $8.55(\mathrm{~d}, 1 \mathrm{H}, J=7.5 \mathrm{~Hz}), 8.06-8.01(\mathrm{~m}, 3 \mathrm{H}), 7.90(\mathrm{~d}, 2 \mathrm{H}, J=8.5 \mathrm{~Hz}), 7.79(\mathrm{~s}, 1 \mathrm{H}), 7.77(\mathrm{~s}$, $1 \mathrm{H}), 7.72(\mathrm{~d}, J=7.5 \mathrm{~Hz}), 7.41-7.32(\mathrm{~m}, 2 \mathrm{H}), 6.33(\mathrm{~d}, 1 \mathrm{H}, J=6.0 \mathrm{~Hz}), 3.56(\mathrm{~s}, 2 \mathrm{H}), 3.24(\mathrm{t}, 2 \mathrm{H}$, $J=6.5 \mathrm{~Hz}), 1.69(\mathrm{t}, 2 \mathrm{H}, J=7.0 \mathrm{~Hz}) .{ }^{13} \mathrm{C}-\mathrm{NMR}\left(100 \mathrm{MHz}, \mathrm{CD}_{3} \mathrm{OD}\right) \delta 163.4,162.6,155.6,144.4$, 143.6, 141.8, 131.7, 127.4, 125.4, 124.3, 123.3, 118.8, 115.7, 40.2, 34.8, 29.2. LC-MS ( $\mathrm{m} / \mathrm{z})$ for $\mathrm{C}_{21} \mathrm{H}_{19} \mathrm{~F}_{3} \mathrm{~N}_{6} \mathrm{O}_{2} \mathrm{~S}: 476.12$, found: $477.20(\mathrm{M}+1)^{+}$.

$\mathrm{N}$-(3-((4-(1H-benzo [ $d$ ]imidazol-1-yl) pyrimidin-2-yl) amino)propyl)-4-methoxy benzenesulfonamide (12m): viscous oil (70\%). ${ }^{1} \mathrm{H}-\mathrm{NMR}\left(400 \mathrm{MHz}, \mathrm{CD}_{3} \mathrm{OD}\right) \delta 8.89(\mathrm{~s}, 1 \mathrm{H}), 8.40$ $(\mathrm{d}, 1 \mathrm{H}, J=5.0 \mathrm{~Hz}), 7.90(\mathrm{~s}, 1 \mathrm{H}), 7.71-7.63(\mathrm{~m}, 3 \mathrm{H}), 7.30-7.24(\mathrm{~m}, 2 \mathrm{H}), 7.01-6.97(\mathrm{~m}, 1 \mathrm{H}), 6.83(\mathrm{~d}$, $2 \mathrm{H}, J=7.0 \mathrm{~Hz}), 6.20(\mathrm{~d}, 1 \mathrm{H}, J=4.0 \mathrm{~Hz}), 3.66(\mathrm{~s}, 3 \mathrm{H}), 3.41(\mathrm{~s}, 2 \mathrm{H}), 2.96(\mathrm{t}, 2 \mathrm{H}, J=7.0 \mathrm{~Hz}), 1.77$ $(\mathrm{p}, 2 \mathrm{H}, J=7.0 \mathrm{~Hz}) .{ }^{13} \mathrm{C}-\mathrm{NMR}\left(100 \mathrm{MHz}, \mathrm{CD}_{3} \mathrm{OD}\right) \delta 163.2,162.8,155.4,154.0,143.6,141.8$, $131.6,128.7,124.2,123.2,118.8,115.8,113.8,103.5,54.7,40.7,37.9,28.7$. LC-MS $(m / z)$ for $\mathrm{C}_{21} \mathrm{H}_{22} \mathrm{~N}_{6} \mathrm{O}_{3} \mathrm{~S}: 438.14$, found: $439.11(\mathrm{M}+1)^{+}$.

$N$-(3-((4-(1H-benzo [d]imidazol-1-yl) pyrimidin-2-yl) amino) propyl)naphthalene-1sulfonamide (12n): white solid (72\%), m.p. 85-87 ${ }^{\circ} \mathrm{C} .{ }^{1} \mathrm{H}-\mathrm{NMR}\left(400 \mathrm{MHz}\right.$, DMSO- $\left.d_{6}\right) \delta 9.02$ $(\mathrm{s}, 1 \mathrm{H}), 8.49(\mathrm{~d}, 1 \mathrm{H}, J=6.5 \mathrm{~Hz}), 8.42(\mathrm{~s}, 1 \mathrm{H}), 8.07(\mathrm{~s}, 4 \mathrm{H}), 7.95(\mathrm{~d}, 1 \mathrm{H}, J=7.0 \mathrm{~Hz}), 7.86-7.80$ $(\mathrm{m}, 3 \mathrm{H}), 7.75(\mathrm{~d}, 1 \mathrm{H}, J=7.0 \mathrm{~Hz}), 7.67-7.59(\mathrm{~m}, 2 \mathrm{H}), 7.33(\mathrm{~d}, 2 \mathrm{H}, J=5.5 \mathrm{~Hz}), 6.36(\mathrm{~d}, 1 \mathrm{H}$, $J=5.0 \mathrm{~Hz}), 3.44(\mathrm{~s}, 2 \mathrm{H}), 2.95(\mathrm{~s}, 2 \mathrm{H}), 1.75(\mathrm{~s}, 2 \mathrm{H}) .{ }^{13} \mathrm{C}-\mathrm{NMR}\left(100 \mathrm{MHz}, \mathrm{DMSO}-d_{6}\right) \delta 156.0$, 155.2, 145.0, 142.5, 137.9, 134.5, 132.1, 129.8, 129.5, 129.0, 128.2, 128.0, 128.0, 124.5, 123.5, 122.7, 120.2, 116.0, 104.0, 41.1, 38.2, 29.2. LC-MS (m/z) for $\mathrm{C}_{24} \mathrm{H}_{22} \mathrm{~N}_{6} \mathrm{O}_{2} \mathrm{~S}: 458.15$, found: $459.20(\mathrm{M}+1)^{+}$.

\subsection{In Vitro Anticancer Activity}

\subsubsection{Anticancer Screening over 60 Cell Lines}

Anticancer profiling over a panel of 60 cancer cell lines was carried out at the National Cancer Institute (NCI), Bethesda, Maryland, USA, https://dtp.cancer.gov/discovery_ development/nci-60/methodology.htm (Last visit 22 September 2021), using the standard procedure (detailed procedure is located in the Supplementary Information page $50 \mathrm{~s}$ ).

\subsubsection{Antiproliferative Effect over A 375 and SK-MEL-5}

The effect of final target compounds over A375 and SK-MEL-5 was performed using reported procedures [48] (detailed procedure is located in the Supplementary Information page 51s).

\subsection{Enzyme Assay}

The enzymatic assays were performed in Reaction Biology Corp. using the standard protocol at $1 \mu \mathrm{M}$ ATP and threefold dilution factor (detailed procedure is found in the Supplementary Information page $52 \mathrm{~s}$ ).

\subsection{Cell Cycle Analysis}

In the beginning, the $\mathrm{IC}_{50}$ of compound 12e over T-47D (American Type Culture Collection, US) was determined using MTT assay, and the same procedure was applied for A375 and SK-MEL-5. T-47D cells (105 cells) were treated with 12e $(5 \mu \mathrm{M})$ and incubated for $48 \mathrm{~h}$. Cells were collected by trypsinization, washed two times with ice-cold PBS, and re-suspended in $60 \%$ cold ethanol and kept at $4{ }^{\circ} \mathrm{C}$ for $60 \mathrm{~min}$. PBS was used to wash the fixed cells and was re-suspended in $1.0 \mathrm{~mL}$ of PBS containing $10 \mu \mathrm{g} / \mathrm{mL}$ propidium iodide and $50 \mu \mathrm{g} / \mathrm{mL}$ RNAase A. Cells were incubated in the dark at $37^{\circ} \mathrm{C}$ for $20 \mathrm{~min}$; then, DNA contents were analyzed using flow cytometric analysis using an FL2 ( $\lambda$ ex/em 535/617 nm) signal detector. For each sample, 12,000 events were acquired. The cell cycle distribution was obtained by using ACEA NovoExpress ${ }^{\mathrm{TM}}$ software [51]. 


\subsection{Molecular Docking}

Crystal structure of the V600EBRAF protein in complex with vemurafenib (PLX-4032) was downloaded from the Protein Data Bank [52] (PDB, ID: 3OG7). The missing amino acid residues of the protein in the crystal structure were modelled using the CHARMM-GUI web-server [53]. Molecular docking, parametrization of the protein structure and studied compounds, visualization of the binding poses, and 2D interaction diagrams were carried out using ICM-PRO software [54]. Colors in 2D interaction diagrams (Figure 5) represent the following: green: hydrophobic region, blue: hydrogen bond acceptor, gray parabolas: accessible surface for large areas, and dashed arrows: hydrogen bonds. The mfScore of ICM-PRO software and MMPBSA method were used for the binding energy estimation. For MMPBSA calculations, the following script https://github.com/sahakyanhk/iPBSA (Last visit on 22 August 2021). which uses the ff14SB force field for protein parameterization, and General Amber Force Field (GAFF) with AM1-BCC charge model for small molecule parametrization, were used [55].

\subsection{Molecular Dynamics Simulations}

The AMBER 20 software package was used for the molecular dynamics simulation [56]. Protein parametrimization was performed using ff14SB force field, while general amber force field (GAFF) with AM1-BCC charge model was used for the ligand parameterization. Docked conformations of three studied compounds (12i, 12e and 12l) and reference ligand obtained from previous stage was used as a starting points for corresponding molecular dynamics simulations. Complexes of V600EBRAF (PDB, ID: 3OG7, chain A) with studied compounds and reference ligand were solvated in the TIP3P water model and $\mathrm{Na}+/ \mathrm{Cl}-$ ions at $150 \mathrm{mM}$ concentration [57]. The Monte Carlo barostat (reference pressure at 1 bar) [58] and Langevin thermostat (collision frequency: gamma_ln $2 \mathrm{ps}^{-1}$ ) [59] were used to keep the temperature at $310.15 \mathrm{~K}$. We used a $1 \mathrm{~nm}$ cutoff for the long-range electrostatic interactions using The Particle Mesh Ewald (PME) method. The first 5 ns of all performed simulations were system minimization and equilibration steps. Each of the generated complexes underwent $100 \mathrm{~ns}$ of conventional molecular dynamics simulation. Finally, for every simulation, binding free energies were used, wherein binding affinity was calculated using MMGBSA and MMPBSA methods using MMPBSA.py program [60]. A total of 250 snapshots with equal intervals collected from the last $20 \mathrm{~ns}$ for every simulation were used for binding energy calculations.

Supplementary Materials: The following are available online at https:/ /www.mdpi.com/article/10 .3390/ijms221910491/s1.

Author Contributions: M.S.A.-M., A.A.B.M. and R.M.H. participated in molecular design and chemical synthesis in addition to spectral data interpretation. M.A.A., S.S. and M.S.A.-B. participated in cellular assay and interpretation of biological activities. G.C. performed molecular modeling study. M.M.A.-S. project coordinator, general supervision and participated in manuscript writing with M.S.A.-M. All authors have read and agreed to the published version of the manuscript.

Funding: The authors extend their appreciation to the Deputyship for Research and Innovation, Ministry of Education in Saudi Arabia for funding this work through the project number 375213500.

Institutional Review Board Statement: Not applicable.

Informed Consent Statement: Not applicable.

Data Availability Statement: Not applicable.

Acknowledgments: M. M. Al-Sanea and M. S. Abdel-Maksoud extend their appreciation to the Korea Institute of Science and Technology (KIST) for funding this work through the grant "2021 KIST School Partnership Project." Also we would like to Acknowledge NCI for performing 60 cell lines assay.

Conflicts of Interest: The authors declare no conflict of interest. 


\section{References}

1. Trivedi, P.; Adhikari, N.; Amin, S.A.; Jha, T.; Ghosh, B. Design, synthesis and biological screening of 2-aminobenzamides as selective hdac3 inhibitors with promising anticancer effects. Eur. J. Pharm. Sci. 2018, 124, 165-181. [CrossRef]

2. Hassan, R.M.; Abd-Allah, W.H.; Salman, A.M.; El-Azzouny, A.A.; Aboul-Enein, M.N. Design, synthesis and anticancer evaluation of novel 1,3-benzodioxoles and 1,4-benzodioxines. Eur. J. Pharm. Sci. 2019, 139, 105045. [CrossRef]

3. Sung, H.; Ferlay, J.; Siegel, R.L.; Laversanne, M.; Soerjomataram, I.; Jemal, A.; Bray, F. Global cancer statistics 2020: Globocan estimates of incidence and mortality worldwide for 36 cancers in 185 countries. CA Cancer J. Clin. 2021, 71, 209-249. [CrossRef] [PubMed]

4. Hao, Y.P.; Liu, Z.Y.; Xie, C.; Zhou, L.; Sun, X. Novel fluorinated docetaxel analog for anti-hepatoma: Molecular docking and biological evaluation. Eur. J. Pharm. Sci. 2016, 88, 274-281. [CrossRef] [PubMed]

5. Al-Sanea, M.M.; Gotina, L.; Mohamed, M.F.; Grace Thomas Parambi, D.; Gomaa, H.A.M.; Mathew, B.; Youssif, B.G.M.; Alharbi, K.S.; Elsayed, Z.M.; Abdelgawad, M.A.; et al. Design, synthesis and biological evaluation of new hdac1 and hdac2 inhibitors endowed with ligustrazine as a novel cap moiety. Drug Des. Devel. Ther. 2020, 14, 497-508. [CrossRef] [PubMed]

6. Sumimoto, H.; Imabayashi, F.; Iwata, T.; Kawakami, Y. The braf-mapk signaling pathway is essential for cancer-immune evasion in human melanoma cells. J. Exp. Med. 2006, 203, 1651-1656. [CrossRef] [PubMed]

7. Fecher, L.A.; Amaravadi, R.K.; Flaherty, K.T. The mapk pathway in melanoma. Curr. Opin. Oncol. 2008, 20, 183-189. [CrossRef]

8. Abdelazem, A.Z.; Al-Sanea, M.M.; Park, B.S.; Park, H.M.; Yoo, K.H.; Sim, T.; Park, J.B.; Lee, S.H.; Lee, S.H. Synthesis and biological evaluation of new pyrazol-4-ylpyrimidine derivatives as potential ros1 kinase inhibitors. Eur. J. Med. Chem. 2015, 90, 195-208. [CrossRef]

9. Al-Sanea, M.M.; Elkamhawy, A.; Paik, S.; Lee, K.; El Kerdawy, A.M.; Syed Nasir Abbas, B.; Joo Roh, E.; Eldehna, W.M.; Elshemy, H.A.H.; Bakr, R.B.; et al. Sulfonamide-based 4-anilinoquinoline derivatives as novel dual aurora kinase (aurka/b) inhibitors: Synthesis, biological evaluation and in silico insights. Bioorg. Med. Chem. 2020, 28, 115525. [CrossRef]

10. Davies, H.; Bignell, G.R.; Cox, C.; Stephens, P.; Edkins, S.; Clegg, S.; Teague, J.; Woffendin, H.; Garnett, M.J.; Bottomley, W.; et al. Mutations of the braf gene in human cancer. Nature 2002, 417, 949-954. [CrossRef]

11. Pollock, P.M.; Meltzer, P.S. A genome-based strategy uncovers frequent braf mutations in melanoma. Cancer Cell 2002, 2, 5-7. [CrossRef]

12. Di Nicolantonio, F.; Martini, M.; Molinari, F.; Sartore Bianchi, A.; Arena, S.; Saletti, P.; De Dosso, S.; Mazzucchelli, L.; Frattini, M.; Siena, S. Wild-type braf is required for response to panitumumab or cetuximab in metastatic colorectal cancer. J. Clin. Oncol. 2008, 26, 5705-5712. [CrossRef]

13. Nikiforova, M.N.; Kimura, E.T.; Gandhi, M.; Biddinger, P.W.; Knauf, J.A.; Basolo, F.; Zhu, Z.; Giannini, R.; Salvatore, G.; Fusco, A.; et al. Braf mutations in thyroid tumors are restricted to papillary carcinomas and anaplastic or poorly differentiated carcinomas arising from papillary carcinomas. J. Clin. Endocrinol. Metab. 2003, 88, 5399-5404. [CrossRef] [PubMed]

14. Kimura, E.T.; Nikiforova, M.N.; Zhu, Z.; Knauf, J.A.; Nikiforov, Y.E.; Fagin, J.A. High prevalence of braf mutations in thyroid cancer: Genetic evidence for constitutive activation of the ret/ptc-ras-braf signaling pathway in papillary thyroid carcinoma. Cancer Res. 2003, 63, 1454-1457. [PubMed]

15. Trovisco, V.; de Castro, I.V.; Soares, P.; Maximo, V.; Silva, P.; Magalhaes, J.; Abrosimov, A.; Guiu, X.M.; Sobrinho-Simoes, M. Braf mutations are associated with some histological types of papillary thyroid carcinoma. J. Pathol. 2004, 202, 247-251. [CrossRef] [PubMed]

16. Hoeflich, K.P.; Herter, S.; Tien, J.; Wong, L.; Berry, L.; Chan, J.; O’Brien, C.; Modrusan, Z.; Seshagiri, S.; Lackner, M. Antitumor efficacy of the novel raf inhibitor gdc-0879 is predicted by brafv600e mutational status and sustained extracellular signal-regulated kinase/mitogen-activated protein kinase pathway suppression. Cancer Res. 2009, 69, 3042-3051. [CrossRef] [PubMed]

17. McDermott, U.; Sharma, S.V.; Dowell, L.; Greninger, P.; Montagut, C.; Lamb, J.; Archibald, H.; Raudales, R.; Tam, A.; Lee, D.; et al. Identification of genotype-correlated sensitivity to selective kinase inhibitors by using high-throughput tumor cell line profiling. Proc. Natl. Acad. Sci. USA 2007, 104, 19936-19941. [CrossRef]

18. Solit, D.B.; Garraway, L.A.; Pratilas, C.A.; Sawai, A.; Getz, G.; Basso, A.; Ye, Q.; Lobo, J.M.; She, Y.; Osman, I.; et al. Braf mutation predicts sensitivity to mek inhibition. Nature 2006, 439, 358-362. [CrossRef]

19. Wan, P.T.; Garnett, M.J.; Roe, S.M.; Lee, S.; Niculescu-Duvaz, D.; Good, V.M.; Jones, C.M.; Marshall, C.J.; Springer, C.J.; Barford, D.; et al. Mechanism of activation of the raf-erk signaling pathway by oncogenic mutations of b-raf. Cell 2004, 116, 855-867. [CrossRef]

20. Wellbrock, C.; Ogilvie, L.; Hedley, D.; Karasarides, M.; Martin, J.; Niculescu-Duvaz, D.; Springer, C.J.; Marais, R. V599eb-raf is an oncogene in melanocytes. Cancer Res. 2004, 64, 2338-2342. [CrossRef]

21. Chapman, P.B.; Hauschild, A.; Robert, C.; Haanen, J.B.; Ascierto, P.; Larkin, J.; Dummer, R.; Garbe, C.; Testori, A.; Maio, M.; et al. Improved survival with vemurafenib in melanoma with braf v600e mutation. N. Engl. J. Med. 2011, 364, 2507-2516. [CrossRef] [PubMed]

22. Bucheit, A.D.; Davies, M.A. Emerging insights into resistance to braf inhibitors in melanoma. Biochem. Pharmacol. 2014, 87, 381-389. [CrossRef]

23. Al-Sanea, M.M.; Abdelazem, A.Z.; Park, B.S.; Yoo, K.H.; Sim, T.; Kwon, Y.J.; Lee, S.H. Ros1 kinase inhibitors for molecular-targeted therapies. Curr. Med. Chem. 2016, 23, 142-160. [CrossRef] 
24. Wilhelm, S.; Carter, C.; Lynch, M.; Lowinger, T.; Dumas, J.; Smith, R.A.; Schwartz, B.; Simantov, R.; Kelley, S. Discovery and development of sorafenib: A multikinase inhibitor for treating cancer. Nat. Rev. Drug. Discov. 2006, 5, 835-844. [CrossRef] [PubMed]

25. Wilhelm, S.M.; Adnane, L.; Newell, P.; Villanueva, A.; Llovet, J.M.; Lynch, M. Preclinical overview of sorafenib, a multikinase inhibitor that targets both raf and vegf and pdgf receptor tyrosine kinase signaling. Mol. Cancer Ther. 2008, 7, 3129-3140. [CrossRef] [PubMed]

26. Bollag, G.; Tsai, J.; Zhang, J.; Zhang, C.; Ibrahim, P.; Nolop, K.; Hirth, P. Vemurafenib: The first drug approved for braf-mutant cancer. Nat. Rev. Drug. Discov. 2012, 11, 873-886. [CrossRef] [PubMed]

27. Qu, M.; Liu, Z.; Zhao, D.; Wang, C.; Zhang, J.; Tang, Z.; Liu, K.; Shu, X.; Yuan, H.; Ma, X. Design, synthesis and biological evaluation of sulfonamide-substituted diphenylpyrimidine derivatives (sul-dppys) as potent focal adhesion kinase (fak) inhibitors with antitumor activity. Bioorg. Med. Chem. 2017, 25, 3989-3996. [CrossRef]

28. Liu, H.; Qu, M.; Xu, L.; Han, X.; Wang, C.; Shu, X.; Yao, J.; Liu, K.; Peng, J.; Li, Y.; et al. Design and synthesis of sulfonamidesubstituted diphenylpyrimidines (sfa-dppys) as potent bruton's tyrosine kinase (btk) inhibitors with improved activity toward b-cell lymphoblastic leukemia. Eur. J. Med. Chem. 2017, 135, 60-69. [CrossRef]

29. Gibney, G.T.; Zager, J.S. Clinical development of dabrafenib in braf mutant melanoma and other malignancies. Expert. Opin. Drug Metab. Toxicol. 2013, 9, 893-899. [CrossRef]

30. Bryan, M.C.; Falsey, J.R.; Frohn, M.; Reichelt, A.; Yao, G.; Bartberger, M.D.; Bailis, J.M.; Zalameda, L.; Miguel, T.S.; Doherty, E.M.; et al. N-substituted azaindoles as potent inhibitors of cdc7 kinase. Bioorg. Med. Chem. Lett. 2013, 23, 2056-2060. [CrossRef]

31. Nofal, Z.M.; Soliman, E.A.; Abd El-Karim, S.S.; El-Zahar, M.I.; Srour, A.M.; Sethumadhavan, S.; Maher, T.J. Novel benzimidazole derivatives as expected anticancer agents. Acta Pol. Pharm. 2011, 68, 519-534.

32. Shaharyar, M.; Abdullah, M.M.; Bakht, M.A.; Majeed, J. Pyrazoline bearing benzimidazoles: Search for anticancer agent. Eur. J. Med. Chem. 2010, 45, 114-119. [CrossRef] [PubMed]

33. Refaat, H.M. Synthesis and anticancer activity of some novel 2-substituted benzimidazole derivatives. Eur. J. Med. Chem. 2010, 45, 2949-2956. [CrossRef] [PubMed]

34. Paul, K.; Sharma, A.; Luxami, V. Synthesis and in vitro antitumor evaluation of primary amine substituted quinazoline linked benzimidazole. Bioorg. Med. Chem. Lett. 2014, 24, 624-629. [CrossRef]

35. Tonelli, M.; Simone, M.; Tasso, B.; Novelli, F.; Boido, V.; Sparatore, F.; Paglietti, G.; Pricl, S.; Giliberti, G.; Blois, S.; et al. Antiviral activity of benzimidazole derivatives. Ii. Antiviral activity of 2-phenylbenzimidazole derivatives. Bioorg. Med. Chem. 2010, 18, 2937-2953. [CrossRef] [PubMed]

36. Kharitonova, M.I.; Konstantinova, I.D.; Miroshnikov, A.I. Benzimidazole nucleosides: Antiviral and antitumour activities and methods of synthesis. Russ. Chem. Rev. 2018, 87, 1111-1138. [CrossRef]

37. Li, Y.F.; Wang, G.F.; He, P.L.; Huang, W.G.; Zhu, F.H.; Gao, H.Y.; Tang, W.; Luo, Y.; Feng, C.L.; Shi, L.P.; et al. Synthesis and anti-hepatitis b virus activity of novel benzimidazole derivatives. J. Med. Chem. 2006, 49, 4790-4794. [CrossRef]

38. Elnima, E.I.; Zubair, M.U.; Al-Badr, A.A. Antibacterial and antifungal activities of benzimidazole and benzoxazole derivatives. Antimicrob. Agents Chemother. 1981, 19, 29-32. [CrossRef] [PubMed]

39. Singla, P.; Luxami, V.; Paul, K. Benzimidazole-biologically attractive scaffold for protein kinase inhibitors. Rsc. Adv. 2014, 4, 12422-12440. [CrossRef]

40. Waller, P.J. Anthelmintic resistance. Vet. Parasitol. 1997, 72, 391-405. [CrossRef]

41. Martin, R.J. Modes of action of anthelmintic drugs. Vet. J. 1997, 154, 11-34. [CrossRef]

42. Brown, H.; Matzuk, A.; Ilves, I.; Peterson, L.; Harris, S.; Sarett, L.; Egerton, J.; Yakstis, J.; Campbell, W.; Cuckler, A.C. Antiparasitic drugs. Iv. 2-(4'-thiazolyl)-benzimidazole, a new anthelmintic. J. Am. Chem. Soc. 1961, 83, 1764-1765. [CrossRef]

43. Abdel-Maksoud, M.S.; El-Gamal, M.I.; Lee, B.S.; Gamal El-Din, M.M.; Jeon, H.R.; Kwon, D.; Ammar, U.M.; Mersal, K.I.; Ali, E.M.H.; Lee, K.T.; et al. Discovery of new imidazo[2,1-b]thiazole derivatives as potent pan-raf inhibitors with promising in vitro and in vivo anti-melanoma activity. J. Med. Chem. 2021, 64, 6877-6901.

44. El-Gamal, M.I.; Khan, M.A.; Tarazi, H.; Abdel-Maksoud, M.S.; Gamal El-Din, M.M.; Yoo, K.H.; Oh, C.H. Design and synthesis of new raf kinase-inhibiting antiproliferative quinoline derivatives. Part 2: Diarylurea derivatives. Eur. J. Med. Chem. 2017, 127, 413-423. [CrossRef] [PubMed]

45. Abdel-Maksoud, M.S.; El-Gamal, M.I.; El-Din, M.M.G.; Kwak, S.S.; Kim, H.I.; Oh, C.H. Broad-spectrum antiproliferative activity of a series of 6-(4-fluorophenyl)-5-(2-substituted pyrimidin-4-yl)imidazo[2,1-b]thiazole derivatives. Med. Chem. Res. 2016, 25, 824-833. [CrossRef]

46. Abdel-Maksoud, M.S.; Ammar, U.M.; El-Gamal, M.I.; Gamal El-Din, M.M.; Mersal, K.I.; Ali, E.M.H.; Yoo, K.H.; Lee, K.T.; Oh, C.H. Design, synthesis, and anticancer activity of imidazo[2,1-b]oxazole-based raf kinase inhibitors. Bioorg. Chem. 2019, 93, 103349. [CrossRef] [PubMed]

47. Ali, E.M.; El-Telbany, R.F.A.; Abdel-Maksoud, M.S.; Ammar, U.M.; Mersal, K.I.; Zaraei, S.-O.; El-Gamal, M.I.; Choi, S.-I.; Lee, K.-T.; Kim, H.-K. Design, synthesis, biological evaluation, and docking studies of novel (imidazol-5-yl) pyrimidine-based derivatives as dual brafv600e/p38 $\alpha$ inhibitors. Eur. J. Med. Chem. 2021, 215, 113277. [PubMed]

48. Abdel-Maksoud, M.S.; Ali, E.M.H.; Ammar, U.M.; Mersal, K.I.; Yoo, K.H.; Oh, C.H. Design and synthesis of novel pyrrolo[2,3b]pyridine derivatives targeting (v600e)braf. Bioorg. Med. Chem. 2020, 28, 115493. [CrossRef] 
49. Eldehna, W.M.; Nocentini, A.; Elsayed, Z.M.; Al-Warhi, T.; Aljaeed, N.; Alotaibi, O.J.; Al-Sanea, M.M.; Abdel-Aziz, H.A.; Supuran, C.T. Benzofuran-based carboxylic acids as carbonic anhydrase inhibitors and antiproliferative agents against breast cancer. ACS Med. Chem. Lett. 2020, 11, 1022-1027. [CrossRef]

50. Vogel, A.I.; Furniss, B.S.; Hannaford, A.J.; Smith, P.W.; Tatchell, A.R. Vogel's Textbook of Practical Organic Chemistry; Longman Scientific \& Technical: London, UK, 1989; Volume 5.

51. Al-Warhi, T.; Abo-Ashour, M.F.; Almahli, H.; Alotaibi, O.J.; Al-Sanea, M.M.; Al-Ansary, G.H.; Ahmed, H.Y.; Elaasser, M.M.; Eldehna, W.M.; Abdel-Aziz, H.A. Novel [(n-alkyl-3-indolylmethylene)hydrazono]oxindoles arrest cell cycle and induce cell apoptosis by inhibiting cdk2 and bcl-2: Synthesis, biological evaluation and in silico studies. J. Enzyme Inhib. Med. Chem. 2020, 35, 1300-1309. [CrossRef]

52. Berman, H.M.; Westbrook, J.; Feng, Z.; Gilliland, G.; Bhat, T.N.; Weissig, H.; Shindyalov, I.N.; Bourne, P.E. The protein data bank. Nucleic Acids Res. 2000, 28, 235-242. [CrossRef]

53. Jo, S.; Kim, T.; Iyer, V.G.; Im, W. Charmm-gui: A web-based graphical user interface for charmm. J. Comput. Chem. 2008, 29, 1859-1865. [CrossRef]

54. Abagyan, R.; Totrov, M.; Kuznetsov, D. Icm-A new method for protein modeling and design: Applications to docking and structure prediction from the distorted native conformation. J. Comput. Chem. 1994, 15, 488-506. [CrossRef]

55. Sahakyan, H. Improving virtual screening results with $\mathrm{mm} / \mathrm{gbsa}$ and mm/pbsa rescoring. J. Comput. Aided Mol. Des. 2021, 35, 731-736. [CrossRef] [PubMed]

56. Case, D.A.; Cheatham, T.E.; Darden, T.; Gohlke, H.; Luo, R.; Merz, K.M.; Onufriev, A.; Simmerling, C.; Wang, B.; Woods, R.J. The amber biomolecular simulation programs. J. Comput. Chem. 2005, 26, 1668-1688. [CrossRef]

57. Jorgensen, W.L.; Chandrasekhar, J.; Madura, J.D.; Impey, R.W.; Klein, M.L. Comparison of simple potential functions for simulating liquid water. J. Chem. Phys. 1983, 79, 926-935. [CrossRef]

58. Oliver, D.S.; Cunha, L.B.; Reynolds, A.C. Markov chain monte carlo methods for conditioning a permeability field to pressure data. Math. Geol. 1997, 29, 61-91. [CrossRef]

59. Wu, X.W.; Brooks, B.R. Self-guided langevin dynamics simulation method. Chem. Phys. Lett. 2003, 381, 512-518. [CrossRef]

60. Miller, B.R., III; McGee, T.D., Jr.; Swails, J.M.; Homeyer, N.; Gohlke, H.; Roitberg, A.E. Mmpbsa. Py: An efficient program for end-state free energy calculations. J. Chem. Theory Comput. 2012, 8, 3314-3321. [CrossRef] 